\title{
Archeological Monitoring for Levee Repair, Navarro County, Texas
}

Marie Huhnke

Geo-Marine, Inc.

Follow this and additional works at: https://scholarworks.sfasu.edu/ita

Part of the American Material Culture Commons, Archaeological Anthropology Commons, Environmental Studies Commons, Other American Studies Commons, Other Arts and Humanities Commons, Other History of Art, Architecture, and Archaeology Commons, and the United States History Commons

Tell us how this article helped you.

This Article is brought to you for free and open access by the Center for Regional Heritage Research at SFA ScholarWorks. It has been accepted for inclusion in Index of Texas Archaeology: Open Access Gray Literature from the Lone Star State by an authorized editor of SFA ScholarWorks. For more information, please contact cdsscholarworks@sfasu.edu. 


\section{Archeological Monitoring for Levee Repair, Navarro County, Texas}

Creative Commons License

(c) (i)@(ङ)

This work is licensed under a Creative Commons Attribution-NonCommercial-No Derivative Works 4.0 International License. 


\title{
ARCHEOLOGICAL MONITORING FOR LEVEE REPAIR, NAVARRO COUNTY, TEXAS
}

\author{
by \\ Marie H. Huhnke
}

for

U.S. Army Corps of Engineers

Fort Worth District

MISCELLANEOUS REPORTS OF INVESTIGATIONS

NUMBER 283

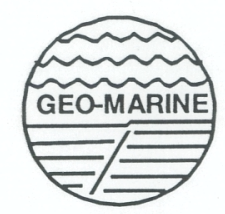

GEOMARINE, INC.

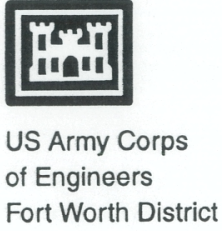




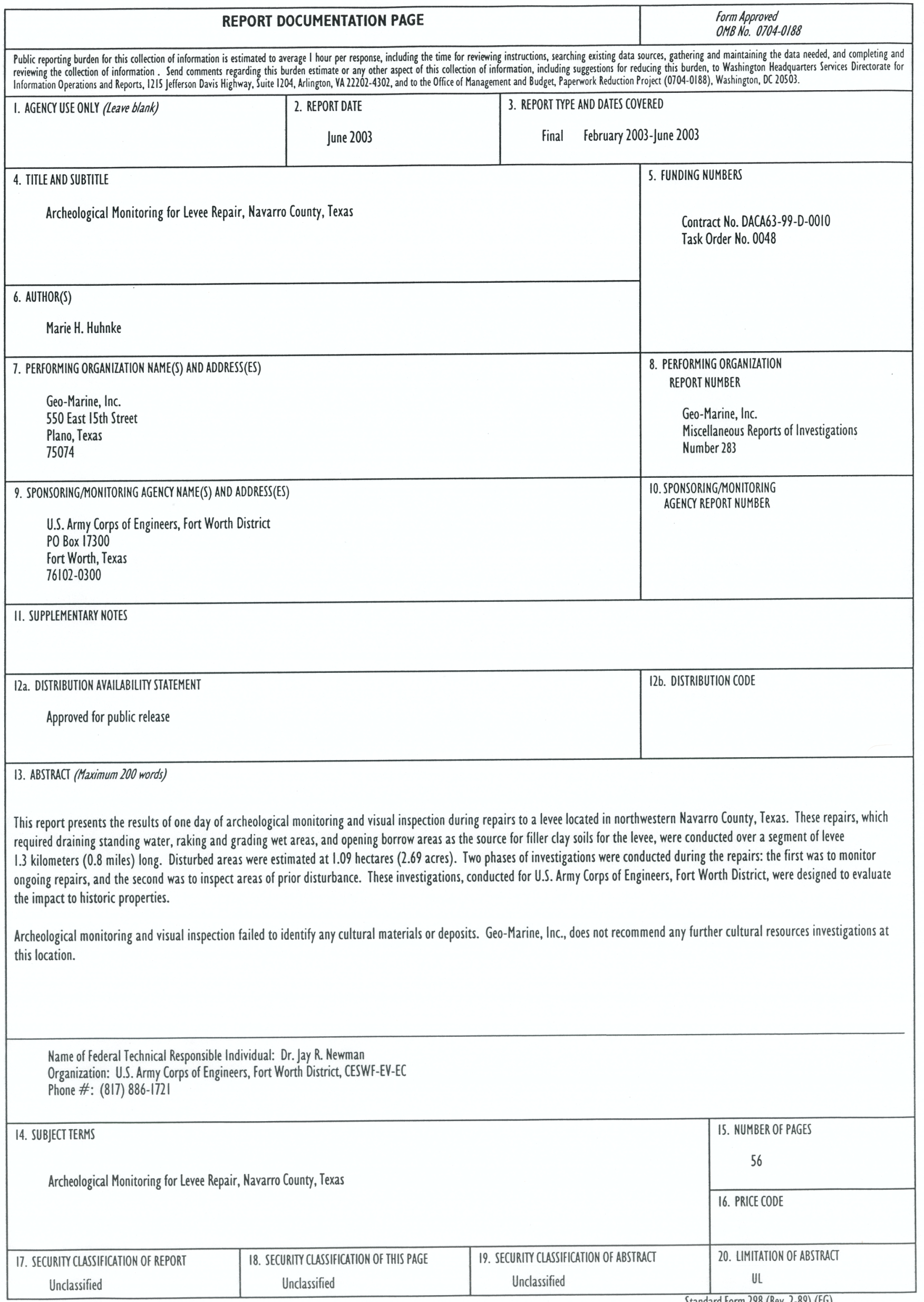





\title{
ARCHEOLOGICAL MONITORING FOR LEVEE REPAIR, NAVARRO COUNTY, TEXAS
}

\author{
by \\ Marie H. Huhnke
}

Principal Investigator

Melissa Green

\author{
for \\ U.S. Army Corps of Engineers \\ Fort Worth District \\ 819 Taylor Street \\ Fort Worth, Texas 76102
}

MisCELLANEOUS REPORTS OF INVESTIGATIONS

NUMBER 283

Geo-Marine, Inc.

550 East 15 th Street

Plano, Texas 75074

June 2003 


\section{CONTRACT DATA}

This document was prepared under Contract No. DACA63-99-D-0010, Delivery Order No. 0048

(GMI Project No. 10100.00.48), for the U.S. Army Corps of Engineers, Fort Worth District, in Navarro County, Texas. 


\section{EXECUTIVE SUMMARY}

This report presents the results of one day of archeological monitoring and visual inspection during repairs to a levee located in northwestern Navarro County, Texas. These repairs, which required draining standing water, raking and grading wet areas, and opening borrow areas as the source for filler clay soils for the levee, were conducted over a segment of levee 1.3 kilometers (0.8 miles) long. Disturbed areas were estimated at 1.09 hectares $(2.69$ acres $)$. Two phases of investigations were conducted during the repairs: the first was to monitor ongoing repairs, and the second was to inspect areas of prior disturbance. These investigations, conducted for the U.S. Army Corps of Engineers, Fort Worth District, were designed to evaluate the impact to historic properties.

Archeological monitoring and visual inspection failed to identify any cultural materials or deposits. Geo-Marine, Inc., does not recommend any further cultural resources investigations at this location. 



\section{TABLE OF CONTENTS}

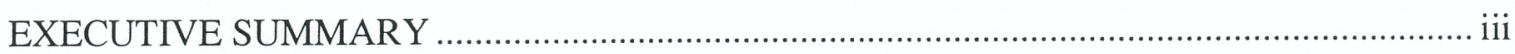

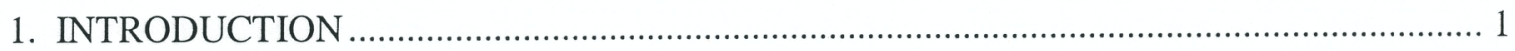

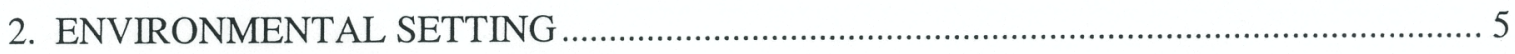

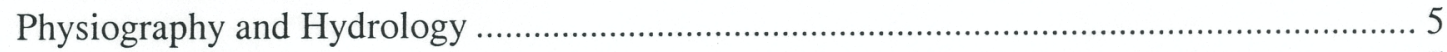

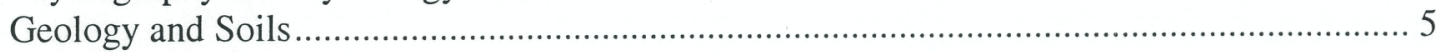

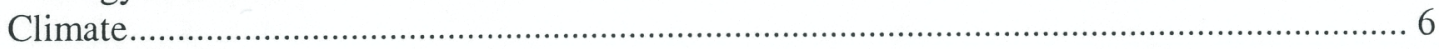

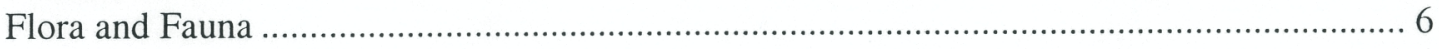

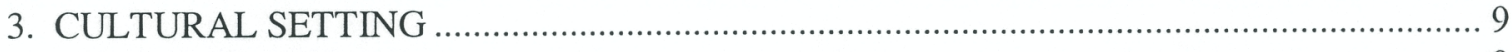

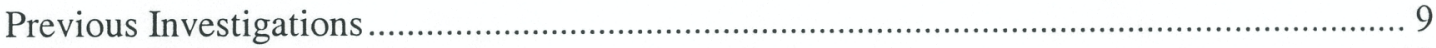

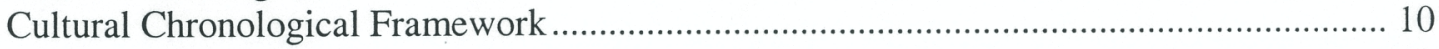

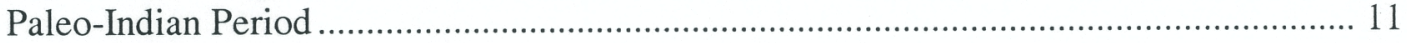

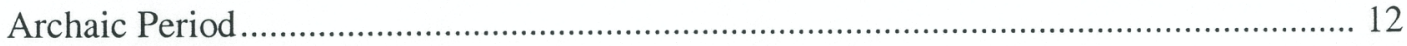

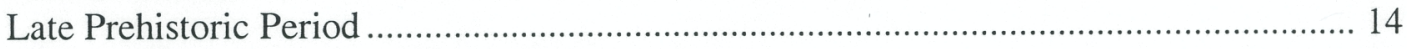

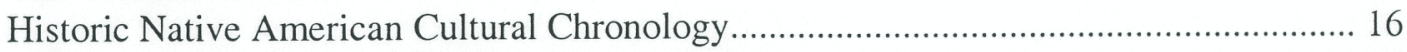

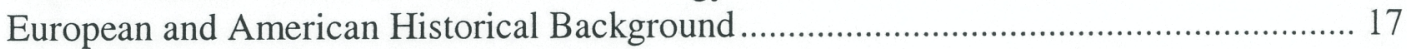

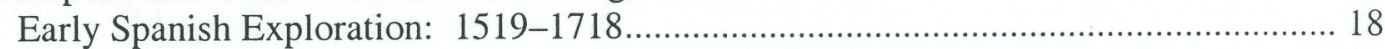

Spanish and French Colonial Activities in Northcentral Texas: 1718-1821 ................ 18

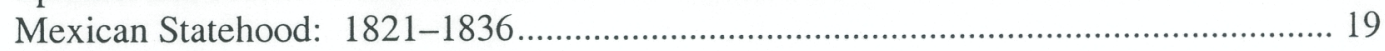

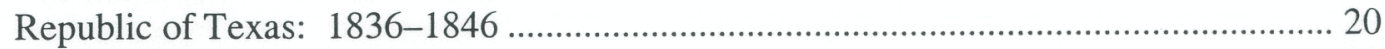

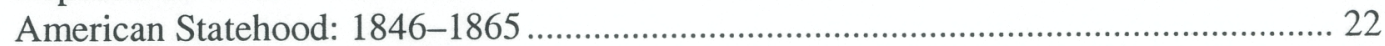

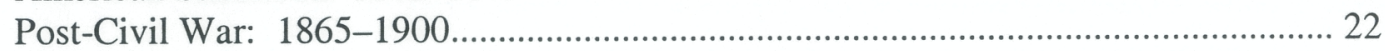

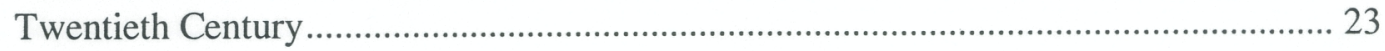

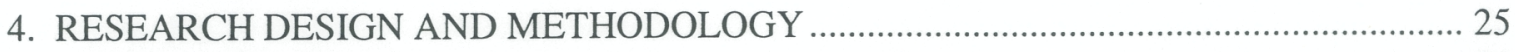

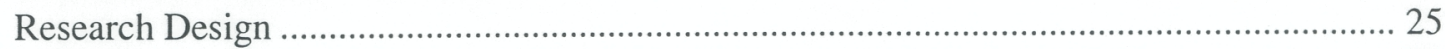

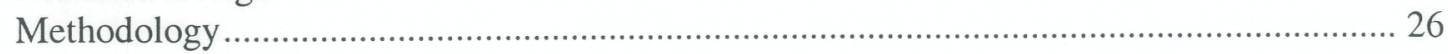

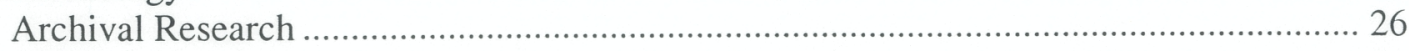

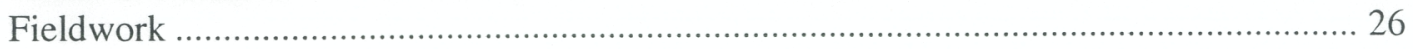


Table of Contents

(cont'd)

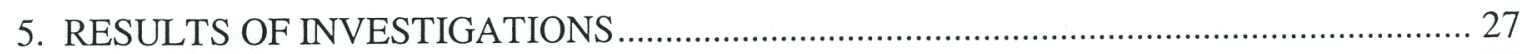

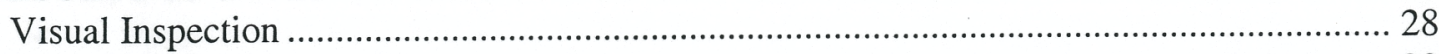

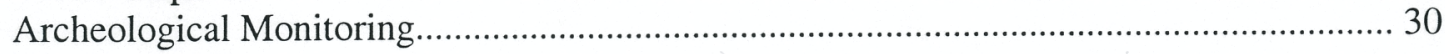

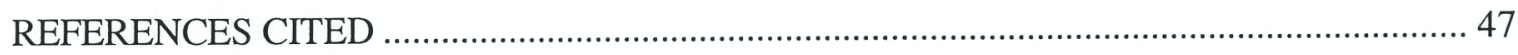




\section{LIST OF FIGURES}

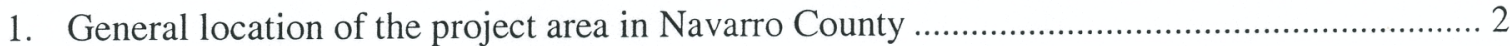

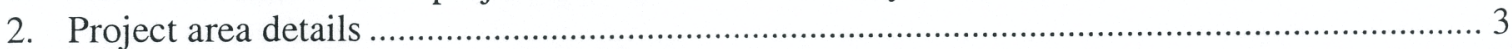

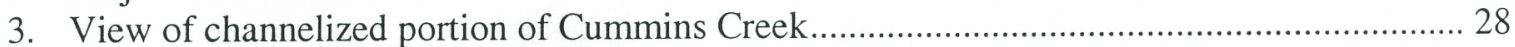

4. View of Cummins Creek and Southern Pacific Railroad......................................................... 29

5. Channelized portion of Cummins Creek; levee is in the foreground ...................................... 30

6. View of the levee parallel to the Southern Pacific Railroad ................................................... 31

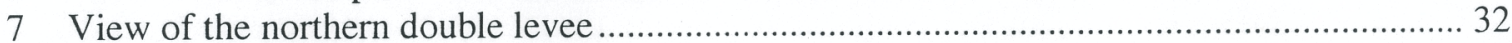

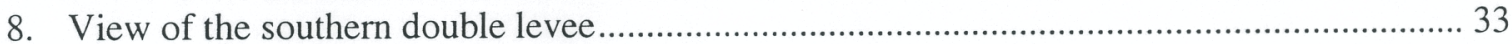

9. View of LR 1 looking southwesterly towards the Old Channel. ........................................ 34

10. View of BA 1 located between the railroad berm and the levee ........................................... 35

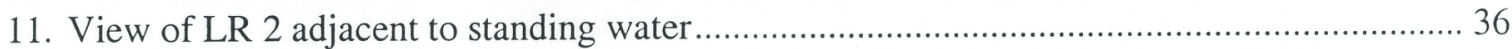

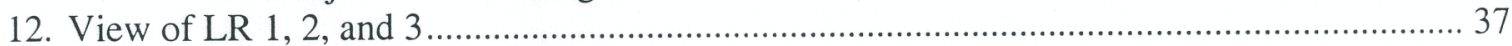

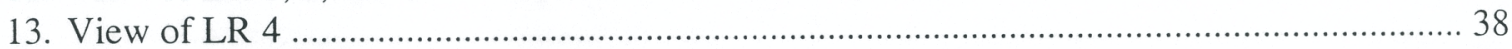

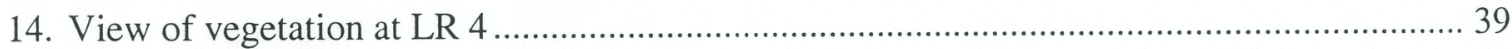

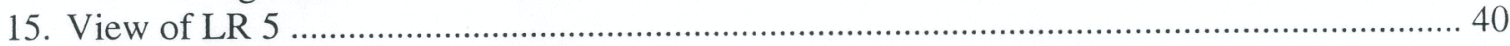

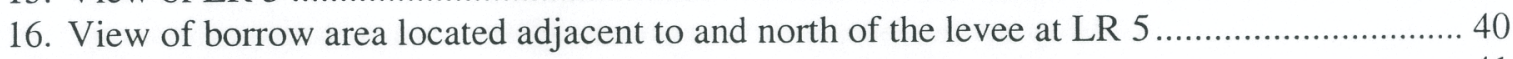

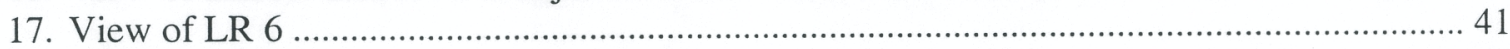

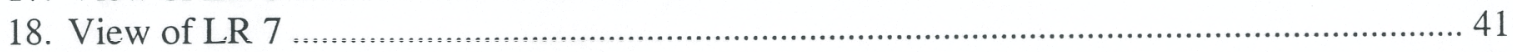

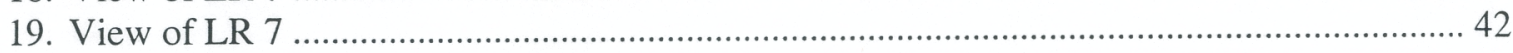

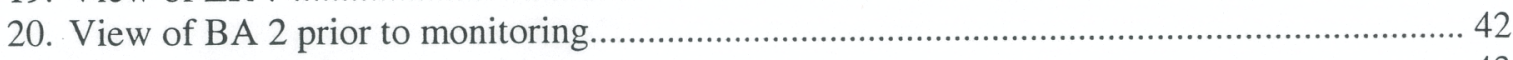

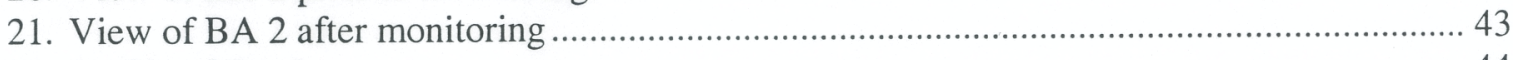

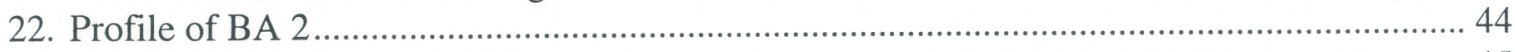

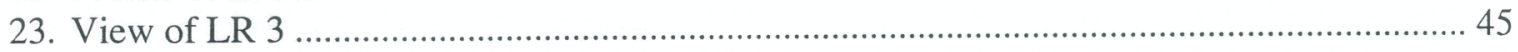





\section{LIST OF TABLES}

1. Native American Chronology for the Middle Trinity River Basin........................................ 10 



\section{CHAPTER 1 INTRODUCTION}

This report presents the results of one day of archeological monitoring and visual inspection during repairs to a levee located in northwestern Navarro County, Texas (Figure 1). Navarro County, as a municipal agency, was required to complete an environmental assessment (EA) prior to levee repairs. As a result of that EA, archeological monitoring during the repairs was recommended. Geo-Marine, Inc. (GMI), was contracted after the repairs were almost completed to conduct the archeological monitoring of the remaining repairs and to assess whether evidence of cultural deposits existed in the now disturbed repair locations. GMI, of Plano, Texas, conducted the cultural resources investigations (GMI project number 10100.00.48) for the U.S. Army Corps of Engineers (USACE), Fort Worth District, in Navarro County, Texas, under Contract No. DACA63-99-D-0010, Delivery Order No. 0048. These investigations were carried out in accordance with, and in partial fulfillment of, the USACE, Fort Worth District, legal obligations under the National Historic Preservation Act (NHPA) of 1966, as amended through 2001 (16 U.S.C. $\S 470$ et seq.; P.L. 89-665; 80 Stat. 915); the Archeological and Historical Preservation Act (AHPA) of 1974, as amended (16 U.S.C. $\S 469$ et seq.; P.L. 93-291; 88 Stat. 174); the National Environmental Policy Act (NEPA) of 1969 (42 U.S.C. §§ 4321-4347; P.L. 91-190; 83 Stat. 852); and Executive Order 11593, "Protection and Enhancement of the Cultural Environment." The cultural resources investigations were designed to monitor levee repairs and to determine the presence or absence of archeological deposits with sufficient contextual integrity to provide significant data concerning the prehistoric and historic occupation of the area.

This linear project area is located west of Interstate 45 (I-45) between Rice and Corsicana and south of Farm-to-Market (FM) 1126 in Navarro County, Texas. The project area spanned 1,463 meters ( $\mathrm{m} ; 4,800$ feet [ft]) of levee. A small 61-m-long (200-ft) segment of the project area abuts Cummins Creek. A larger portion $(670.6 \mathrm{~m}[2,200 \mathrm{ft}])$ of the project area lies adjacent to the Southern Pacific Railroad, and another portion nearly equal in size $(731.5 \mathrm{~m}[2,400 \mathrm{ft}])$ involves the levee on the Waxahachie Slough (Figure 2).

Frequent flooding had caused the levee to wash out in seven areas. Repairs to these washouts were made by building up the levee with fill soil taken from adjacent borrow areas. Therefore, impacted areas consisted of levee repair areas (LRs 1, 2, and 3), borrow areas (BAs 1 and 2), and double levee repair and adjacent borrow areas (LR 4, 5, 6, and 7). The cultural resources investigations consisted entirely of monitoring repairs in progress at LR 3 and BA 2 and a thorough visual inspection of LR 1,2, and 4-7 and BA 1 (see Figure 2). 


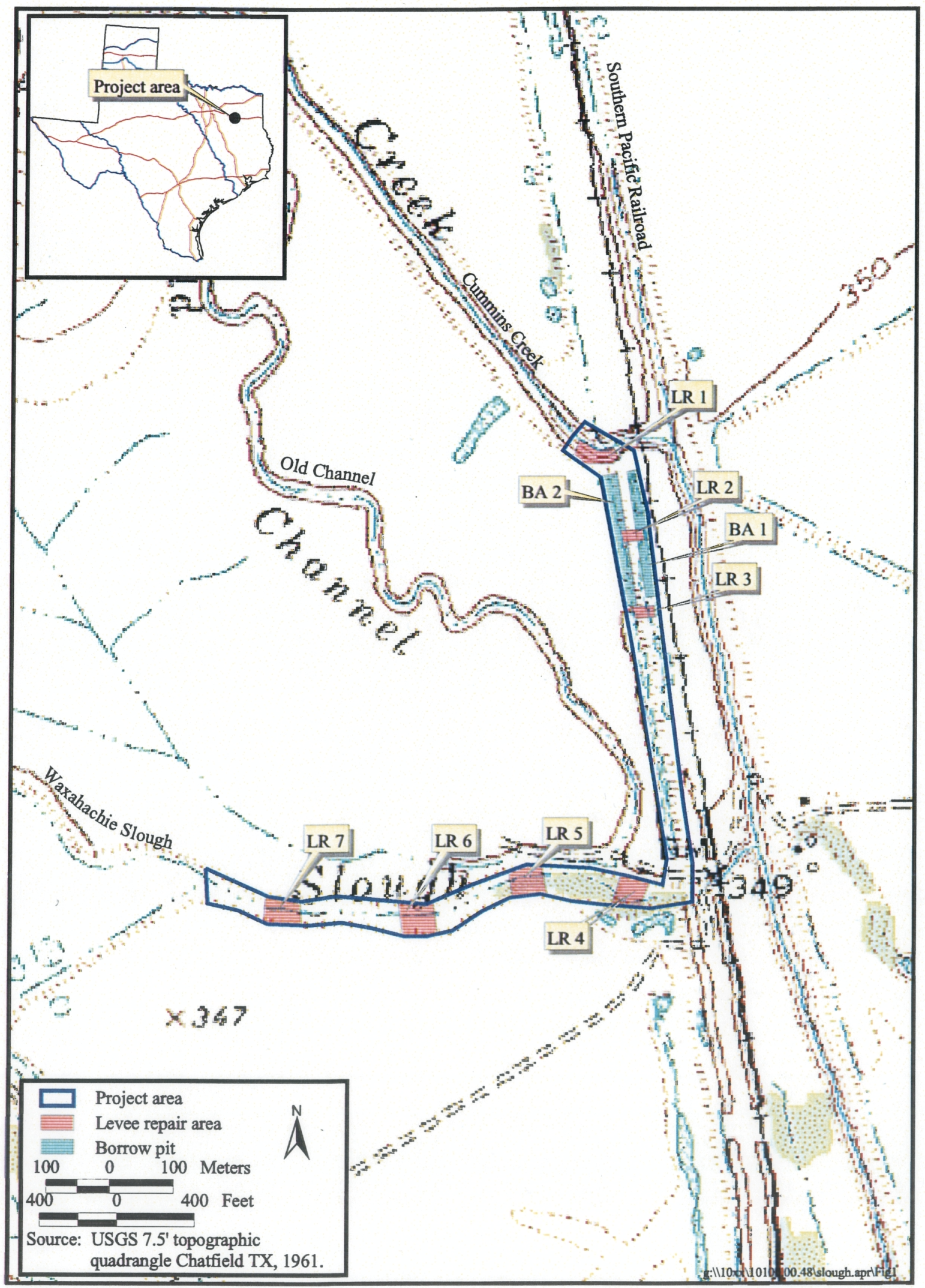

Figure 1. General location of the project area in Navarro County, Texas. 


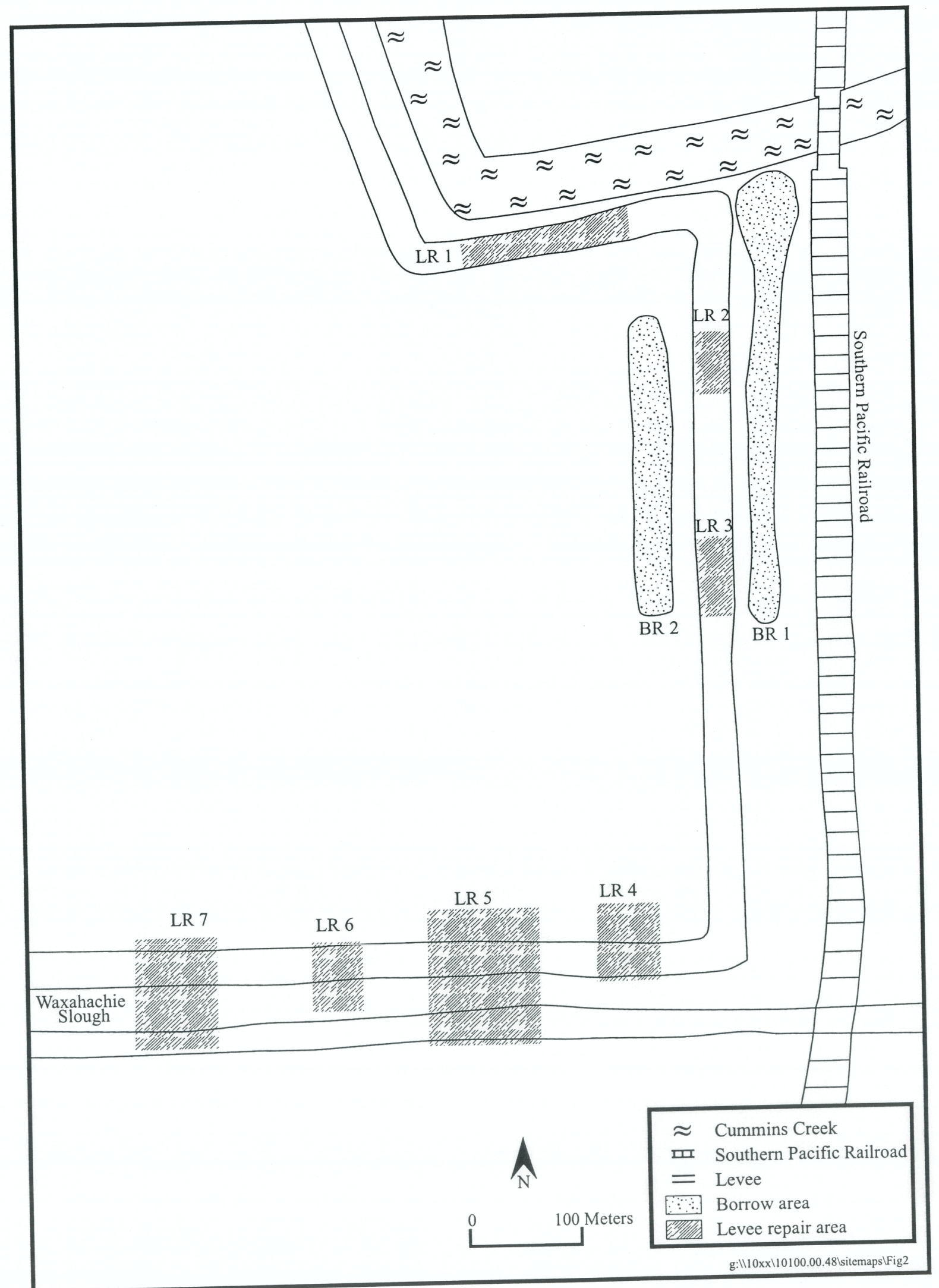

Figure 2. Project area details. 
All previously disturbed areas involved approximately .90 hectare (ha; 2.21 acres [ac]). Of this amount, approximately 0.28 ha $(0.69 \mathrm{ac})$ were disturbed in order to drain standing water by raking the soils and then grading (BA 1). The double levee and adjacent borrow areas equaled approximately .57 ha $(1.40 \mathrm{ac})$. Finished repairs to the main levee involved .05 ha $(.12 \mathrm{ac})$. Disturbances that were monitored totaled $.20 \mathrm{ha}(.12 \mathrm{ac})$. The estimated depth of disturbances to all areas except BA 2 is $1 \mathrm{~m}(3.28 \mathrm{ft})$. At BA 2, where the active repairs were observed, disturbances were observed to a depth of $1.5 \mathrm{~m}(4.92 \mathrm{ft})$.

Geo-Marine Project Archeologist Marie Huhnke conducted the field investigations on February 4, 2003. Melissa Green served as Principal Investigator. Prior to fieldwork, a literature and archival search was initially conducted to determine if any recorded sites were present within the project area. Site records at the Texas Archeological Research Laboratory (TARL) at the University of Texas at Austin were also consulted. A deed and title research, however, was not conducted. Fieldwork documentation consisted of recording and interpreting soils encountered during the monitoring and inspection, documenting field observations, and photographically recording the progress of project activities.

Including this introduction, the report presents the environmental and archeological contexts of the project area (Chapters 2 and 3), the monitoring methodology (Chapter 4), the results of the archeological investigations (Chapter 5), and recommendations (Chapter 6). References cited in the text follow the main body of the report. 


\section{CHAPTER 2 ENVIRONMENTAL SETTING}

\section{PHYSIOGRAPHY AND HYDROLOGY}

The project area is located in northwestern Navarro County, just west of I-45, between Rice and Corsicana. Environmentally, the project area is located in the middle Trinity River basin. The predominant physiographic zone is the Blackland Prairie, which is bordered to the east by the Oak Woodlands. Low rolling plains covered with black, calcareous clay soils and dissected with numerous streams characterize the Blackland Prairie. These soils support a dominance of grasses, primarily little bluestem and Indiangrass; shrubs and trees are present along stream bottoms and flood plains (Diamond et al. 1987).

Cummins Creek flows southeasterly into Waxahachie Slough, which joins with Chambers Creek, a tributary of Richland Creek. Richland Creek is a major tributary of the middle Trinity River downstream of its confluence with its major branches, the East Fork, Elm Fork, West Fork, Clear Fork, and Little Elm Creek. Both Chambers and Richland creeks flow in an easterly direction and have Holocene flood plains approximately 3-5 km (1.9-3.1 mi) wide (McGowen et al. 1972).

\section{GEOLOGY AND SOILS}

Geologically, 95 percent of the project area is underlain by Holocene alluvium and Quaternary deposits, undivided. The remaining 5 percent consists of Upper Cretaceous Wolfe City sand, which in Navarro County is composed of sandy and silty marl, interbedded with thin sandstone beds and massive sandstone. The formation grades northward into a fine-grained sand and silt calcareous unit (Bureau of Economic Geology 1972).

The majority of the project area soils (95 percent) belong to the Trinity-Kaufman association and the remainder ( 5 percent) to the Houston Black-Heiden association. The Trinity-Kaufman soils are fine-textured, calcareous and noncalcareous soils located on bottomlands. These flood plain soils consist of 74 percent Trinity soils and 13 percent Kaufman soils. The Houston BlackHeiden association is composed of fine-textured, very slowly permeable, calcareous soils, with Houston Black soils comprising 34 percent of the association and Heiden soils accounting for 31 percent. The remainder of the association is made up of minor soils. 
Two soil units are mapped in the project area. The levees, which account for approximately 20 percent of the project area, are made up of Trinity soils, frequently flooded. Eighty percent is composed of Trinity clay located on flood plains. This very dark gray clay is very firm with calcareous inclusions (Meade et al. 1974).

\section{CLIMATE}

The climate in Navarro County is humid subtropical, with hot summers. Prevailing winds are southerly, except during the winter months, when northerly winds prevail. These southerly winds are a result of the tropical maritime air masses originating in the Gulf of Mexico, which dominate during the late spring, summer, and early fall. Winters are warm with a daily minimum average of $34.7^{\circ}$ Fahrenheit (F) during January; the average frost-free period in Navarro County is 253 days per year. Summers are hot, with little rainfall and a daily maximum average temperature of $97.3^{\circ} \mathrm{F}$ during August.

Precipitation, falling mostly in thundershowers during the spring and early summer, is a result of the interaction of polar air masses and moisture-laden air from the Gulf of Mexico. Rains are of high intensity and result in rapid runoff. Thundershowers during April, May, and June account for 13 inches of rain; total annual rainfall is 37 inches (Meade et al. 1974).

\section{FLORA AND FAUNA}

Navarro County is located in the Texan biotic province defined by Blair (1950) as an intermediate zone between the eastern forests of the Austroriparian and Carolinian provinces and the western grasslands of the Kansan, Balconian, and Tamaulipan provinces. Yates and Ferring (1986:22) explain that the Texan province is not so much a distinct geographic unit as it is a giant ecotone, in which species from both the forests to the east and the grasslands to the west overlap at the limits of their ranges. The region as a whole is characterized by high species diversity (Yates and Ferring 1986:22). The Blackland Prairie portion of the Texan biotic province consists of one of several tall-grass prairies prevalent in this portion of Texas. Overstory, where it occurs, consists of open stands of live oak (Quercus fusiformus), with occasional intermixtures of southern red oak (Quercus falcata), willow oak (Quercus phellos), and white oak (Quercus alba). Minor overstory species include black willow (Salix nigra), cottonwood (Populus deltoides), red ash (Alphitonia excels), sycamore (Platanus occidentalis), cedar elm (Ulmus crassifola), American elm (Ulmus americanus), bois d'arc (Maclura pomifera), and mesquite (Prosopis glandulosa). Riparian environments often support stands of pecan (Carya illinoinensis), plum (Prunus americana), hackberry (Celtis reticula), black walnut (Juglans nigra), and similar trees, many of which would have been important food resources in prehistoric times.

Understory consists mostly of perennial "bunch" grasses such as little bluestem (Schizachyrium scoparium), silver bluestem (Barthriochloa saccaroides), blue grama (Bouteloua gracilis), sideoats grama (Bouteloua curtipendula), hairy grama (Bouteloua hirsuta), and Indiangrass (Sorghastum avenaceum), among others. Other common plant species in the region include several varieties of briar (Rubus sp.), rock cress (Arabis petiolaris), few-seed sedge (Carex oligocarpa), marigold dogweed (Dyssodia tagetoides), Texas bluegrass (Poa arachnifera), and butterweed (Senecio glabenus). Also present are the fragmented remains of the tall-grass prairie that once dominated this region. 
A wide variety of faunal species occurs in the area; Blair (1950) cites a total of 57 mammalian species for the Texan biotic province. Also noted by Blair are 16 species of lizard, one species of land turtle (Terrapene ornata), 36 species of snakes, and 22 species of amphibians. Blair makes no mention of birds, although some 320 avian species are known to exist in the region (Winnette 1990). Common bird species include mourning dove (Zenaida macroura), bobwhite quail (Colinus virginianus), and turkey vulture (Cathartes aura).

Riparian environments are important habitats for such species as the fox squirrel (Sciurus niger), opossum (Didelphis marsupialis), and turkey (Meleagris gallapavo silvestrous). Grasslands and similar open habitats support the white-tailed deer (Odocoileus virginianus), cotton rat (Sigmodon grammacus), striped skunk (Mephitis mephitis), nine-banded armadillo (Dasypus novemcinctus), red fox (Canis rufus), and gray fox (Urocyon cinereoarhenteus). Aquatic environments provide habitat for raccoons (Procyon lotor) and the occasional mink (Mustela vison) and muskrat (Ondatra zibethicus); many species of fish, including catfish (Ictalurus and Pylodictus spp.), sunfish (Lepomis spp.), and freshwater drum (Aplodinotus grunniens); various watersnakes and amphibians; migrating waterfowl; and shorebirds. Enterprising species that have colonized human habitats include the black rat (Rattus rattus), house mouse (Mus musculus), and house sparrow (Passer domesticus). Local species that are now considered threatened or endangered include the mountain lion (Felis concolor), osprey (Pandion halietus), prairie falcon (Falco mexicanus), and merlin (Falco columbiarus). Several species that may have historically inhabited the area, such as pronghorn antelope (Antilocapra americana) and bison (Bison bison), are locally extinct, but predator species such as the coyote (Canis latrans) and the bobcat (Felis rufus) are not uncommon (Blair 1950:113-115). 



\section{CHAPTER 3 CULTURAL SETTING}

\section{PREVIOUS INVESTIGATIONS}

Previous archeological investigations in the Trinity River basin have focused on the upper basin. On the East Fork of the Trinity River, several projects, including Lavon Lake (Dawson and Sullivan 1973; Lynott 1975; Stephenson 1949) and Lake Ray Hubbard (Harris and Suhm 1963; Lorrain and Hoffrichter 1968; Ross 1966) have made significant contributions to the understanding of cultural processes in the region. Significant archeological projects on the upper Elm Fork of the Trinity in the Dallas-Fort Worth-Denton area include Lake Ray Roberts (Ferring 1987; Ferring and Yates 1997; Prikryl and Yates 1987; Skinner et al. 1982), Lewisville Lake (Brown and Lebo 1991; Ferring and Yates 1998; Stephenson 1950), and Grapevine Lake (Ferring 1975; Morgan 1975). Along the West Fork of the Trinity River and its tributaries, intensive investigations have occurred only at Joe Pool Lake (Peter and McGregor 1988). In the middle Trinity River basin, Anderson County's Cedar Creek Reservoir was initially surveyed in 1961 by the Texas Archeological Salvage Project (TASP). This survey recorded 30 sites dating from the Archaic to the Late Prehistoric periods, and an earlier Paleo-Indian presence in the area was suggested by scattered surface finds of early style projectile points (Guy 1990:58). The TASP excavated three sites in 1964: Wild Bull (41HE61), Lacy (41HE70), and Gossett Bottoms (41KF7; Story 1965). Archaic through Late Prehistoric material occupations were identified at all three sites, and a Paleo-Indian component was also tentatively identified at Wild Bull.

Archeological investigations in the middle Trinity River basin, composed of Cummins, Chambers, and Richland creeks, in the Blackland Prairie, however, vary in intensity and quality. The extensive prehistoric, historic, and environmental investigations conducted by the Richland Creek Archeological Project were carried out in connection with the construction of the RichlandChambers Reservoir on Richland and Chambers creeks in Freestone and Navarro counties, west of Anderson County (Bruseth and Martin 1987; Bruseth and Moir 1987; Jurney and Moir 1987; Bruseth et al. 1987; Moir and Jurney 1987). The reservoir area was intensively surveyed by Southern Methodist University (SMU) in 1980, and 911 archeological sites were recorded. Two hundred seventy of these were subsequently tested, and 106 were judged eligible for the National Register of Historic Places (NRHP); excavations were carried out at 15 prehistoric and 38 historic sites, and architectural studies were conducted at 38 structures, between 1982 and 1984 (Guy 1990:97). This work primarily identified Middle Archaic through Late Prehistoric utilization of 
the area; three Late Prehistoric phases were defined for the Richland-Chambers creek area (i.e., Richland Creek, Round Prairie, and St. Elmo). In addition, some Paleo-Indian and Early Archaic occupations were indicated as well. The historic research focused on mid-nineteenth to midtwentieth century Anglo-American and African-American occupations, most of which were small rural settlements or farmsteads.

Surveys were conducted prior to the construction of the Superconducting Super Collider and Bardwell Lake in Ellis County, Cedar Creek Reservoir in Kaufman and Henderson counties, and Navarro Mills Reservoir in Navarro and Hill counties (see Guy 1990, Prikryl 1993, and Yedlowski et al. 1998 for more detailed information on these and other regionally relevant projects). Because of the location of the Cedar Creek and Richland-Chambers reservoirs on the southeastern margin of the Blackland Prairie, investigations there have revealed more about Native American adaptations to the Oak Woodlands than to the Blackland Prairie.

\section{CULTURAL CHRONOLOGICAL FRAMEWORK}

The culture history sequence of the middle Trinity River basin has been defined largely by a few major reports which have primarily added to an understanding of the Late Prehistoric presence in this area. Summarized in Table 1, the following sequence is based on Bruseth and Moir (1987), Prikryl (1993), Story (1990), and Yedlowski et al. (1998). These large-scale surveys have provided the initial assemblage data necessary for an understanding of the adaptations in the middle Trinity River basin. Although the combined efforts of professional and avocational archeologists have recorded numerous sites, much research remains to be done.

Table 1

Native American Chronology for the Middle Trinity River Basin (after Bruseth and Moir 1987, Prikryl 1993, Story 1990, and Yedlowski et al. 1998)

Temporal Periods and Subdivisions

Years B.C./A.D.

Paleo-Indian $10,000-6500$ B.C.

Archaic

Early

Middle

6500-3000 B.C.

Late

3000-1000 B.C.

1000 B.C.-A.D. 700

Late Prehistoric

Richland Creek Phase

A.D. $700-900$

Round Prairie Phase

A.D. $900-1300$

St. Elmo Phase

A.D. $1300-1650$

Historic Indian

A.D. $1650-1850$ 


\section{Paleo-Indian Period}

The Paleo-Indian period in northcentral Texas (ca. 10,000-6500 B.C.) generally includes those remains of human presence that can be dated to the very late Pleistocene and the immediate postPleistocene periods (for reviews relevant to this period in northcentral Texas, see Hofman 1989a; Johnson 1989; Prikryl 1990; Story 1990). Point types often found that can be associated with the early to late parts of the period include Clovis, Folsom, Dalton, Plainview, San Patrice, and Scottsbluff. Based on a sample of projectile points from surface sites, Prikryl (1990) has suggested that among the most common Paleo-Indian point types in this area are Plainview and Dalton. Ferring and Yates (1997) suggest that these types date to about 9,500-10,000 years ago, based on cross dating with other regions. The suggested age for these types may correspond with the onset of early Holocene alluviation in the Trinity River valley. The majority of the recorded Paleo-Indian sites cluster in the upper Trinity drainage where the most intensive archeological investigations have taken place, though often these sites consist of no more than one or two points. The Acton site, however, located in Hood County on a $\mathrm{T}_{2}$ terrace of the Brazos River overlooking Lake Granbury, is significant for the number of Plainview and Dalton (Meserve) points it produced $(n=72)$. A variety of other lithic tools such as gouges, scrapers, and burins also were recovered. Unfortunately, the Paleo-Indian occupation could not be isolated from Archaic period occupations of the site. As with many other areas of Texas, Paleo-Indian materials in northcentral Texas often are found in surface contexts or mixed with later materials. The generally low density of Paleo-Indian artifacts and sites and the tendency for projectile points to be made from nonlocal lithics have led investigators to characterize these populations as highly mobile with low regional densities (Lynott 1981:100-101). The Paleo-Indian occupation of the upper Trinity River basin is known primarily through diagnostic projectile points from surface collections or from stratigraphically mixed contexts (Meltzer 1987; Meltzer and Bever 1995). The Field Ranch site (41CO10) along the upper Elm Fork is a prime example of typical site contexts (Jensen 1968). Interestingly, the only two investigated sites in northcentral Texas with apparently discrete Paleo-Indian components - the Lewisville and Aubrey sites located in the upper Trinity River basin - are early, both producing Clovis projectile points. The Lewisville site (41DN72) contained 27 hearth features with an associated Clovis point and other sparse lithics (Crook and Harris 1957, 1958; Story 1990:182-184). Although the original radiocarbon dates on the hearths suggested an anomalously early age for Clovis points (ca. 37,000 B.P.), later work by the Smithsonian Institution (Stanford 1981) appears to have resolved the controversy concerning the date of the occupation there. Apparently, the presence of naturally occurring lignite in these hearths, either as a fuel or as an inadvertent inclusion, contaminated the radiocarbon samples. Consequently, the usually accepted date of 12,000-10,000 B.P. for Clovis period occupations is probably a reasonable estimate for the first human occupation of northcentral Texas. The deeply buried Aubrey site (41DN479), located on the Elm Fork of the Trinity River, yielded lithic debitage and Clovis points buried beneath $8 \mathrm{~m}$ of Holocene alluvium on the Elm Fork flood plain (Ferring 1989; Ferring et al. 2001). The discovery of this site suggests that well-preserved PaleoIndian sites in northcentral Texas will only be found by examining deeply stratified Holocene alluvium in modern flood plain situations. The Lewisville and Aubrey sites contained a variety of faunal remains, both large and small; the largest-white-tailed deer-can be associated comfortably with the Clovis occupation at the Lewisville site. The preponderance of small game at the Aubrey site could be interpreted as representing a more generalized pattern of foraging than the reliance on mammoth and bison apparently demonstrated at Clovis sites on the Southern Plains (Hofman 1989a:31-32). Such a divergence in subsistence patterns may reflect an inherent adaptability of Clovis technology to changing environmental conditions encountered as early populations spread southeastward into Texas (Ferring and Yates 1997). 
There are no excavated and reported Paleo-Indian components on the central Blackland Prairie itself. Nonetheless, a variety of early points has been found, largely in surface contexts, and it is clear that this part of Texas was used throughout the period from ca. 10,000 to 6500 B.C. Presumably, this use was by hunter-gatherer groups with low population densities and high residential mobility. An analysis of materials collected by C. K. Chandler and other avocational archeologists from sites chiefly in Ellis County during the Superconducting Super Collider project identified a handful of Paleo-Indian projectile points typed as Clovis, Plainview, Dalton, Golondrina, and San Patrice, along with several untyped lanceolate specimens (Yedlowski et al. 1998). Other early materials from the area include a few San Patrice points from the RichlandChambers Reservoir (Bruseth et al. 1987) and a cache of 23 prismatic blades from a site in Navarro County (Young and Collins 1989).

\section{Archaic Period}

The Archaic period is tentatively dated between ca. 6500 B.C. and A.D. 700, having been subdivided into early, middle, and late divisions (Prikryl 1993:199). Thus, the Early Archaic has been dated from 6500 to 4000 B.C., the Middle Archaic from 4000 to 1500 B.C., and the Late Archaic from 1500 B.C. to A.D. 700. Overviews that cover the Archaic in this portion of Texas include those from Hofman (1989a), Prikryl (1990), and Story (1985, 1990). Diagnostic artifacts for the period are similar to those of adjacent regions, although developing a sound chronological sequence of diagnostic artifacts has proven difficult because many of the investigations have focused on surface manifestations. Prikryl (1990) suggests that Early Archaic projectile points include early split-stemmed varieties and possibly Angostura, and Middle Archaic points include basal-notched forms such as Bell, Andice, and Calf Creek along with Wells, Dawson, Carrollton, and Bulverde. Late Archaic point types reportedly include Castroville, Marshall, Edgewood, Ellis, Trinity, Palmillas, Yarbrough, Dallas, Godley, Elam, and Gary (Prikryl 1990). At one time, the Carrollton and Elam foci were used to define the Middle and Late Archaic, respectively (Crook and Harris 1952, 1954). Reevaluation of the type-site artifacts, however, showed that the materials were so mixed that perpetuation of these foci provides little interpretive value (Hofman et al. 1989; Prikryl 1990). Some of this mixing and the generally low numbers of Early and Middle Archaic sites may be due to extensive erosion of mid-Holocene deposits, as has been documented for the Brazos drainage in Young, Stephens, and Throckmorton counties (Ensor et al. 1992).

Though few isolable components have been analyzed for the various divisions of the Archaic period in northcentral Texas, slowly increasing populations responding to warmer and drier environmental conditions have been postulated to explain the overall archeological record of the period (Lynott 1981; Story 1990). It is thought that these factors may have led Archaic populations of the Cross Timbers and prairie areas of northcentral Texas to develop a diversified hunting and gathering pattern based on bottomland resources of the rivers and major creeks, while populations on the Rolling Plains maintained a focus on bison hunting (Hofman 1989a). Projectile points of the period were fashioned from local lithic materials, suggesting that populations were less mobile than were their Paleo-Indian predecessors. Less mobility also may suggest refinement of the diversified subsistence pattern to include scheduling of resource use within more restricted areas. Evidence from Late Archaic sites at Joe Pool Lake (Peter and McGregor 1988) and Lake Ray Roberts (Ferring and Yates 1997) in the upper Trinity River basin indicates repeated site occupation by small groups, which could support the resource-scheduling 
hypothesis. Still, even with refinement of resource utilization, evidence of dietary stress has been found on Late Archaic human skeletal materials (Ferring and Yates 1997; Gill-King 1987). Additional sites (41WS43 and 41WS44) in Wise County are thought to have been inhabited as temporary Archaic camp occupations (Beene 1996).

Mixing of components also has hampered interpretations regarding the use of the middle Richland-Chambers Creek area of the middle Trinity River by Native Americans during the lengthy Archaic period. Because few pure Archaic components have been excavated, particularly ones dating to the first two-thirds of the period, it is difficult to say much about artifact chronologies, subsistence practices, or settlement strategies. A variety of projectile point styles traditionally associated with the Early and Middle Archaic periods in Central Texas-for example, Andice, Angostura, Bell, Gower, Hoxie, Martindale, Nolan, Travis, and Uvalde (Yedlowski et al. 1998) — was identified during analyses for the Superconducting Super Collider project (although a host of other types perhaps dating to this time and later were identified as well, their chronologies are less certain), but these points are few in number and do not appear to represent a major occupation of this part of the Blackland Prairie. Demonstrably early points were scarce at the Strawn Creek site at Navarro Mills Reservoir (Duffield 1963; Sorrow et al. 1966). Only Wells points and Clear Fork gouges were felt to be potentially diagnostic of the Early Archaic period in the Richland-Chambers Reservoir area. Data pertaining to the Early to Middle Archaic may be scarce in part because sites dating to this interval lie deeply buried or were removed by extensive erosion during the mid-Holocene (Fields 1995; Bruseth et al. 1987). A few radiocarbon assays predating 4,000 B.P. were obtained, but points dated to this interval in Central Texas (for example, Bell/Andice/Calf Creek and Hoxie) occur at the Richland/Chambers Reservoir in only very small numbers.

The Middle Archaic period (3000-1000 B.C.), identified at seven sites within the reservoir (Bruseth and Moir 1987:Figure 18-3) in the Richland-Chambers Reservoir area, is slightly more visible. Dart point types diagnostic of this period include Bulverde, Carrollton, Yarbrough, and possibly Dawson. Waco sinkers and Clear Fork tools were present as well. Small concentrations of burned sandstone were identifiable in excavations at several sites and were interpreted as being subsurface roasting pits of short duration. Based on excavated data, population density was felt to have been low, with reduced group mobility in comparison to the earlier periods. Economically, hunting and gathering was felt to have continued to be of primary importance, with utilized resources including turtle, cottontail rabbit, bird, fish, deer, and hickory nuts. The presence of an unidentified rhizome may also indicate the use of some species of prairie turnip (Psoralea sp. [Bruseth and Moir 1987:234-236]).

A much different picture is presented for the Late Archaic period (after about 4,000 B.P.), which is known from numerous sites in the central Blackland Prairie. Both the Pecan Springs and Strawn Creek sites yielded such Late Archaic point types as Gary, Dawson, and Yarbrough, although they tend to be mixed with materials from later occupations (Duffield 1963; Sorrow et al. 1966). The surface collections analyzed during the Superconducting Super Collider project also contained these types, as well as a number of Late Archaic types common in Central Texas-such as Darl, Ensor, Marcos, Marshall, and Montell-and a variety of probable Late Archaic forms more characteristic of the northern and eastern parts of the state, such as Carrollton, Edgewood, Elam, Ellis, Kent, and Neches River (Yedlowski et al. 1998). Noting the relatively high frequency of Late Archaic projectile points, Yedlowski et al. (1998) suggest that the region saw an increased use by hunter-gatherers as a result of moister climatic conditions than 
before, presumably associated with greater productivity in subsistence resources. They also note that, although the projectile point evidence indicates interaction with groups living in Central Texas proper, larger proportions of points indicate affinities with eastern Texas than during the Early and Middle Archaic.

Fifteen investigated archeological sites in the Richland-Chambers creek area could be placed within the Late Archaic period (1000 B.C-A.D. 700). Subsistence evidence recovered from various sites included deer, turtle, hickory nuts, some form of Psoralea tuber, and a variety of seeds, with sumpweed being most common (Bruseth and Moir 1987:236-240; Table 18-7). In addition to constellations of projectile point styles (e.g., Dawson, Gary, Godley, Kent, Neches River, and Yarbrough) that indicate ties more to the north and east than to the south and west, each of these areas has yielded information suggesting that ceramics may have been introduced into the material culture of local groups at this time. To the east, this interval is usually called the Early Ceramic period, and sometimes the Woodland period (Brown 1987:44-22 through 44-26). At Richland-Chambers Reservoir, distinctive shell-tempered sherds were recovered from contexts dated between A.D. 200 and 700 at the Adams Ranch site (Bruseth et al. 1987:236-240), apparently representing the earliest ceramic industry in this part of the Trinity River basin.

Along Richland and Chambers creeks, Late Archaic groups appear to have been hunter-gatherers whose subsistence pursuits focused on wild plant foods such as hickory nuts and prairie turnip and faunal taxa such as deer, turtles, small mammals, birds, and fish (Bruseth et al. 1987:236240). Although presumably not sedentary, these groups clearly used the area in an intensive fashion for residential purposes, and it appears that populations increased while territory sizes decreased. A conspicuous component of the record is the so-called "Wylie pits," which are large man-made depressions measuring approximately $16 \mathrm{~m}(52.5 \mathrm{ft})$ in diameter and $0.61 \mathrm{~m}(2 \mathrm{ft})$ in depth, excavated at the Bird Point Island and Adams Ranch sites. These large features appear to have been used for communal processing of vegetal resources (and later as cemeteries), perhaps in the context of band aggregation in "tension zones" as territories decreased in size (Bruseth et al. 1987; Prikryl 1993). Wylie pits were in use at Richland-Chambers Reservoir in the Late Archaic (Bruseth and Martin 1987), but radiocarbon assays from pits at the Upper Rockwall and Sister Grove Creek sites in the area of Lake Lavon in the upper Trinity basin suggest an association with the Late Prehistoric period (Lynott 1975; Ross 1966).

\section{Late Prehistoric Period}

The initial appearance of arrow points marks the beginning of the Late Prehistoric period (ca. A.D. 700-1700). These arrow points, ceramics manufacture, and the introduction of cultigens such as corn are important technological changes of the period. Group aggregation and largescale manipulation of subsistence resources represented by habitation structures, indicating increased sedentism, as well as the Wylie pits and the human burials they contain may be indicative of societal changes that continued through the Late Prehistoric period. Also, there may be evidence (e.g., the distinction between burials placed inside and outside of Wylie pits) of differential mortuary practices that could reflect a shift toward a hierarchical social structure, although this evidence is nowhere near as strong as that for the Caddoan area of northeast Texas. Both Lynott (1977) and Prikryl (1990) have proposed that the Late Prehistoric period be divided into an early and a late phase, with the early phase reflecting a continuation of the foraging subsistence system of the preceding Late Archaic period and the late phase reflecting Southern Plains influences. Evidence of horticulture and bison procurement also appears in sites of this period (Harris and Harris 1970; Morris and Morris 1970). 
The Richland Creek phase, dated between A.D. 700 and 900, is the earliest manifestation of the Late Prehistoric in the Richland-Chambers creek area. This phase is characterized by the appearance of the bow and arrow; the predominant projectile point styles were Scallorn and Steiner. Deposits datable to this phase are also associated with dart points, including two small varieties of Gary points. The collections studied during the Superconducting Super Collider project contain substantial numbers of both early (e.g., Alba, Bonham, Catahoula, Colbert, Scallorn, and Steiner) and late (e.g., Cliffton and Perdiz) arrow points, but Yedlowski et al. (1998) note that early arrow points are more frequent, perhaps reflecting continued high population densities from the Late Archaic period. Other than the Perdiz and Scallorn types, which have such widespread distributions, the arrow point styles point eastward and northward. Ceramics increased in importance during this phase with the addition of plain, sandy paste ware and bone-, grog-, and/or grit-tempered ware with punctated or incised decorations, possibly related to Canton Incised. The limited ceramic samples, containing sherds reminiscent of types such as Weches Fingernail Impressed, Killough Pinched, Maydelle Incised, and Poyner Engraved, also support interaction with Caddoan groups to the east (Yedlowski et al. 1998). The Strawn Creek site at Navarro Mills Reservoir presents a similar picture; most of the typed arrow points date to the first half of the Late Prehistoric period, and the more distinctive ceramics in the small collection relate to the early Caddoan types - Crockett Curvilinear Incised and Weches Fingernail Impressed (Duffield 1963). Both small and large roasting pits are present, but overall diminished in size. Clusters of postholes suggest the presence of some type of structures. Faunal remains indicate that fish, cottontail rabbit, deer, and turtle were exploited; occasionally, certain sites demonstrate evidence for specialized exploitation. Plant remains include evidence of Psoralea tubers, hickory nuts, acorns, pecans, and various other seeds (Bruseth and Moir 1987:240-243).

The period between A.D. 900 and 1300 in the Richland-Chambers creek area has been defined as the Round Prairie phase. Artifact assemblages of this phase are characterized by the presence of Alba points in association with the two late varieties of Gary points, as well as by increased frequencies of ceramics, including the punctated and incised types similar to Canton Incised. It has been suggested that the Bird Point Island site (41FT201) was a sedentary occupation at this time. The subsistence economy during this phase was very similar to that of the preceding Richland Creek phase, with similar species being exploited. However, notable additions to the exploitative pattern included bison and jackrabbit, suggesting the closer proximity of grasslands than in the previous period (Bruseth and Moir 1987:243-245).

The final phase of the Late Prehistoric period in the Richland-Chambers area, the period from A.D. 1300 to 1650, has been designated the St. Elmo phase. This phase is characterized by Perdiz and Cliffton arrow points, although a small percentage of Gary dart points are still present in deposits dating to this period. Subsistence resources include bison, deer, cottontail rabbit, jackrabbit, raccoon, and fish, as well as hickory nuts, pecans, acorns, Psoralea, and various seeds. Small amounts of maize are also recovered from these sites, although it is not clear whether it was being cultivated in the Trinity River basin or imported from East Texas. Ceramics are more common in these deposits than ever before and are thus assumed to have been more important. Tempering materials remain the same, but engraving and incising became the dominant decorative techniques, with some design elements resembling those of the Caddoan type, Poynor Engraved. Despite these changes, it has been suggested that settlement patterns become somewhat less sedentary in comparison with the previous phase. A wide-ranging and more mobile economy has been proposed on the basis of structures being less permanent in appearance and an increase in nonlocal lithic materials (Bruseth and Moir 1987:245-247). 


\section{Historic Native American Cultural Chronology}

Prior to Spanish settlement of New Mexico in 1598, European presence in the Southwest and on the Southern Plains was sporadic at best (Coronado in 1540-1541, the Rodriguez-Chamuscado party in 1581, Espejo in 1582-1583). After 1598, however, Spanish influence was never absent from the Southern Plains, although actual contact with Europeans continued to be limited and only brief records of journeys into or through the area exist (Hofman et al. 1989; John 1975).

By the eighteenth century, immigrant Plains Indian groups had moved into and beyond northcentral Texas, and their documentation by traders and explorers marks the start of the Historic period (A.D. 1700 to 1850; Prikryl 1993). Unfortunately, since good historical documentation is very sparse for the upper Trinity River basin during the early Historic era, it is not clear which specific aboriginal groups were residing in the present-day Dallas/Fort Worth area at the beginning of this period. What is clear is that the early Historic period in northcentral Texas was a time of population fluctuation, movement, and amalgamation (see Newcomb 1993).

Documentary sources suggest that the Tonkawa, Apache, Comanche, Wichita, Kitsai, Yojaune, Caddo, Delaware, and Kickapoo traversed the region at various times during the period (Campbell 1983; Newcomb 1961; Newcomb and Campbell 1982). Prior to about 1725-1750, Apachean groups appear to have dominated the western portion of the Southern Plains, known as the High Plains. After that time, the area was increasingly controlled by the Comanche and Kiowa. On the eastern portion of the Southern Plains, within the area now known as the Middle Plains and northcentral Texas, the Wichita tribes became dominant (Bell et al. 1967; Hofman 1989b:91).

Available data suggest that many, if not all, of the aboriginal occupants of the eastern margin of the Great Plains, including northcentral Texas, were Caddoan language speakers, from the Arikara in the north to the Wichita and Kichai in the south. In this light, it is worth noting that it has also been suggested that the Socoatino, encountered by the survivors of the de Soto expedition in the sixteenth century, were Caddoan speakers and were the same as the Canohatino, identified by the French in the latter part of the seventeenth century, apparently located at that time "on the Blackland Prairies between the Guadalupe and Trinity rivers to the east of presentday San Antonio, Austin, and Waco" (Newcomb 1993:24). If the prehistoric occupants of the eastern margin of the plains in Texas were indeed Caddoan speakers, it would explain how they were absorbed very early by other Caddoan-speaking groups (such as the Yojuane, Kichai, Tawakoni, Taovayas, Iscani, and Wichita proper) who arrived in northcentral Texas in the late seventeenth and early eighteenth centuries. Most of these groups, in turn, amalgamated to form the historic Wichita Tribe. Some, however, were probably absorbed by the united Caddo Tribes, and some may even have joined amalgamations of a variety of groups, such as the Tonkawa, during the late eighteenth and early nineteenth centuries.

The term Wichita is commonly used to refer to a group of linguistically related tribes, including the Wichita, Taovayas, Tawakoni, Iscani, Waco, and Kichai. Many of these groups apparently entered the Southern Plains in the seventeenth century, probably from Kansas and southern Nebraska, to escape the hostilities of the Osage (Webb and Carroll 1952:2:904). The Wichita were true Plains Villagers, with an economy that was jointly dependent upon agriculture and bison hunting. They occupied permanent villages of beehive-shaped, grass houses, from which they conducted seminomadic bison hunts. In 1719 their villages were located along the Arkansas River in northern Oklahoma (Hofman 1989b:95). By 1750, they had moved some of their 
villages to southern Oklahoma, along the Red River. Others were located on the upper end of the Sabine and Neches rivers in Texas and subsequently on the middle Trinity and upper Brazos rivers. In 1772, the year they concluded a nominal peace with the Spanish, one of their villages was on the Salt Fork of the Brazos, on the Middle Plains west of present-day Dallas/Fort Worth (John 1975:Map 3; Webb and Carroll 1952:2:705). Wichita groups were included in treaties made with the Republic of Texas in 1843 and with the United States in 1837 and 1856 (Webb and Carroll 1952:2:709). In Texas, they continued to live between the upper Brazos and Trinity rivers until 1855. In that year, the Tawakoni and Waco were placed on the Brazos Indian Reservation, south of Fort Belknap, in company with a number of other Native American remnant groups (Smith 1996; Webb and Carroll 1952:1:212, 2:905). Subsequently, as a result of increasing animosity from white settlers, they were removed to Indian Territory in 1859 (Smith 1996; Webb and Carroll 1952:1:210). The remnants of the Wichita moved to Kansas during the Civil War, but returned to Oklahoma after the war to settle permanently near present-day Anadarko (Hofman 1989b:95).

Although archeological sites that can be associated definitely with various Historic groups are few, sites attributable to the Historic Witchita, who moved into Texas from Oklahoma and Kansas in the early 1700s, have been identified at the edges of northcentral Texas. Among these is the Stansbury site located in Hill County, now inundated by Lake Whitney (Stephenson 1970). Excavations at the site produced burials, house structures, storage pits, and a variety of aboriginal artifacts along with European ceramics, glass beads, metal arrow points, and flintlock musket parts. A cluster of Wichita sites also occurs to the north along the Red River in Montague County. These sites are known collectively as "Spanish Fort" and occur on both the Oklahoma and Texas sides of the river. Woodall (1967) excavated one of these sites, named the Upper Tucker site. The site produced artifacts and features similar to those discovered at the Stansbury site. Wichita sites on both the Brazos and Red rivers were located atop high terraces overlooking the rivers. Within the upper Trinity River basin, little evidence of these Historic Native American groups has been found, with the exception of a few Native American sites with European items (Sollberger 1953).

At the beginning of the nineteenth century, the physical presence of Europeans on the Southern Plains became commonplace. This was the result of increasingly peaceful relations between the Spanish in Texas and the Plains Indians to the north, and the acquisition of Louisiana by the United States in 1803.

\section{European and American Historical Background}

Texas in general has had both a rich and complex history that stretches back almost as far as the presence of Europeans in North America. Texas, and the northcentral region in particular, was not settled by Anglo-Americans, however, until the early 1800s. The following discussion is intended to be only a general overview of this history; for more detail regarding Historic Native Americans and the early European/Euro-American history of Texas, the reader is referred to Campbell (1983), de la Teja (1988), Fehrenbach (1985), Gilmore (1991), Hester (1989), John (1975), Pool (1975), Wedel (1978), and Winship (1990). For the sake of convenience, this section has been divided into several subsections, covering various time periods: Spanish exploration (1519-1718), French and Spanish Colonial activities (1718-1821), Mexican statehood (1821-1836), the Texas Republic (1836-1846), American statehood (1846-1865), post-Civil War (1865-1900), and the twentieth century (post-1900). 
Early Spanish Exploration: 1519-1718

The initial European presence in Texas began in 1519 when Spanish explorer Alonso Alvarez de Piñeda arrived on the Texas coast while exploring the coast of the Gulf of Mexico (Webb 1952a:380). Attempts to explore and colonize continued, and in 1528, Álvar Nuñez Cabeza de Vaca and his party landed on an island known to the Spanish as Malhado, possibly Galveston Island (Webb 1952b:261-262; Winship 1990:1-4). Although Spanish exploration of the region continued with over 90 expeditions into Texas from 1519 to 1731, it was clear by 1550 that there were no golden cities or wealthy countries to conquer north of Mexico. Consequently, Spanish expansion into the American southwest and Texas slowed, leaving eastern Texas largely unexplored.

Around 1542, the survivors of the Hernando de Soto expedition, led by his lieutenant Luís de Moscoso de Alvarado, entered northeast Texas as they attempted to reach New Spain by land (Bruseth and Kenmotsu 1991). During his four-year exploration of the present-day southeast United States, de Soto reached the Mississippi River in May 1541 and spent the rest of that year exploring present-day northern Louisiana and Arkansas. De Soto died in 1542, leaving de Alvarado to guide the expedition overland to Mexico and safety. Alvarado's exact route is unknown, but archeological studies indicate that he apparently traversed the Red River valley somewhere between present-day Shreveport, Louisiana, and Texarkana, Texas. The party crossed the Red River and journeyed through northcentral Texas to present-day Wichita Falls before returning to the Mississippi River to travel to the Gulf of Mexico. Because of de Soto's expedition, Spain claimed the Red River valley as part of its colonial empire (Commercial National Bank of Shreveport, Louisiana [CNB] 1979:8, 34; Cooper et al. 2002; Kelley and Coxe 1996:20).

During the late sixteenth and early seventeenth centuries in southern Texas, tension between the Coahuiltecan groups and the Spanish and between Coahuiltecan groups and the Apaches escalated. This ultimately led to Spanish protection of the Coahuiltecan groups against the Apaches, and the establishment of the first Spanish missions in 1670 (John 1975:172-174). Spanish fear of an increased French presence in Texas led to the decision to establish missions and presidios in East Texas as a buffer against further French encroachment into that region (Cooper et al. 2002; Pool 1975:28; Webb 1952b:483-484). The easternmost Spanish mission was Mission San Francisco de los Tejas, northwest of the present community of Weches near the Neches River (Works Progress Administration [WPA] 1940:37)

\section{Spanish and French Colonial Activities in Northcentral Texas: 1718-1821}

Because present-day northcentral Texas was located on the border of the French and Spanish Colonial spheres of influence, much of the early settlement during the eighteenth century in the counties near the project area were trading posts that were tasked with establishing relations with the Native Americans to gain allies. The three-pronged approach that the Spanish used for settlement-presidio, mission, and civilian colony-proved to be more successful in south Texas, and they had only established two missions on the middle Trinity River by 1756 (Sherman 2001:E$1)$. 
Outside political factors during the latter half of the eighteenth century had a great impact on the development of the region. The French Revolution, and the European monarchies' efforts to stop it, resulted in a decline from the French threat. As a result, mission status was downgraded, and the Spanish missions were secularized by 1793 . Following the sale of Louisiana to the United States in 1803, Anglo-American immigration into northcentral Texas intensified, although for a number of years it was not clear who actually owned the area south of the Red River. The United States considered it (and indeed, most of Texas) to be part of Louisiana and encouraged settlement of the area (Chandler and Howe 1939). Spain, on the other hand (and later Mexico), was violently opposed to this view, and at several times during the first few decades of the nineteenth century, the dispute nearly led to war (Smith 1991). The first official American penetration of the region was by the Freeman-Curtis Expedition of 1806, which was turned back at Spanish Bluffs, along the Red River, by a Spanish military force (Cooper et al. 2002; Flores 1984). By 1810, Spanish rule in northcentral Texas had rapidly deteriorated. The question of territorial ownership was finally settled by the Adams-Onis Treaty (1819), which ceded Florida to the United States for assuming Spanish debts to American citizens. The treaty also defined borders in the west, and the Red River was designated as the border between the two nations. Even though the border with the Spanish was now fixed, other factors arose that restrained settlement in the project area (Cooper et al. 2002; Tindall and Shi 1996:406).

Despite Spain's claim, northcentral Texas was too close to the United States not to fall into the Anglo-American sphere of influence, and settlement from the United States continued. Some of the early settlement mirrored French Colonial practices, such as the establishment of trading places like the pole hut built by a settler known only as "Blue" in the Rattan area of Delta County in 1820 (McCroskey 1997). The earliest permanent settlements were confined to the areas immediately adjacent to the Red River, but after 1818, settlement pushed into the prairies along river tributaries and early roads such as Trammel's Trace and Dayton's Road. Trammel's Trace, a popular immigrant route into Texas after 1813, crossed the Sulphur River at Epperson's Ferry and continued southwestward through Cass County to Hughes Springs, founded in 1839, and then south to cross Cypress Creek two miles west of Jefferson (Webb and Carroll 1952:2:793-794).

\section{Mexican Statehood: 1821-1836}

Following Mexico's independence from Spain in 1821 (May 1991), political, economic, and social conditions in Texas slowly improved. Beginning in 1823, immigration laws were changed to allow empresarios to offer lands to heads of families willing to settle in Texas. The policy had been initially investigated by the Spanish as a means of securing the territory and providing a buffer zone against Indian attack. In fact, Moses Austin had applied for and received permission to bring 300 American colonists to Texas in 1821, prior to Mexican independence (Fehrenbach 1985:135). By the time he returned to his home in Missouri, his health had broken; but before his death, he convinced his son, Stephen, to carry out his plans (Fehrenbach 1985:136).

Stephen F. Austin willingly followed in his father's footsteps. Because of the liberal land policies of first Spain and then later Mexico, he had many eager volunteers ready to accompany him. Colonists had to be of good moral character and were required to become Spanish (then Mexican) citizens. They were also required to convert to Catholicism, although this requirement was not rigorously enforced. Under Spanish/Mexican law, land was distributed as follows: one labor (177 acres) to each family engaged in farming, one league (4,428 acres) to each family engaged 
in ranching, and one-third league (1,476 acres) to each single rancher (Fehrenbach 1985:140; Tindall and Shi 1996:578-579). The government charged a flat title fee, and Austin received a fee. The law required the land to be developed within two years or forfeited. In all, 297 titles were issued and only seven forfeited. Most of the settlers claimed to be ranchers for obvious reasons.

The original Anglo-American settlers in northcentral Texas were apparently largely subsistence farmers residing on small holdings, with an economy reportedly based on grain and livestock production (Peter and Cliff 1990:36). The commercial production of cotton apparently was not introduced until the 1830s (Fehrenbach 1985), a shift that was accompanied by increasing numbers of slaves in the region. By 1830, 1,000 African-American slaves had been brought to the eastern coastal region to serve as labor in the cotton fields (Tindall and Shi 1996:579). The introduction of cotton affected the development of urban areas of northcentral Texas also. The town of Jefferson, founded in 1836 along Cypress Creek, was a major cotton market, and the antebellum planters throughout the region undoubtedly sent their cotton there for sale where it could be shipped to the market of New Orleans down the river (Peter and Cliff 1990:39). Other major industries established to support the growing agriculture about the same time included tan yards, lumber yards, and syrup mills (Webb and Carroll 1952:1:198, 2:59; WPA 1940:379).

One of the effects of increased immigration was the opening and improvement of roadways, many of which followed the Spanish caminos. The influx of settlers into the region brought changes in local politics as well, and Anglo-American immigrants gained more power. Most of the early settlements in northcentral Texas occurred during the 1830s. In many areas of Texas, Mexicans were becoming politically overshadowed by the new immigrants. The Mexican government, alarmed by this situation, passed the Decree of April 6, 1830, which prohibited the further "colonization of Mexican territory by citizens of adjacent countries-meaning the United States" (Fehrenbach 1985:165) and the importation of slaves, which was designed to discourage large-scale farming. This decree further alienated the Anglo-American settlers. From 1832 to 1835, a series of conflicts and temporary solutions continued to drive a wedge between Colonial Texas and Mexico. When meetings were held in San Felipe, the Anglo-American immigrants adopted resolutions and framed a state convention resulting in the formation of a state separate from Coahuila. In 1835, a Mexican army crossed the Rio Grande bound for San Antonio to squelch the rebellious Texans. A call to arms was issued and hostilities were begun in earnest (Fehrenbach 1985:193).

Many of the conflicts, later known as the Texas Revolution, were fought in and around the city of San Antonio. These engagements culminated in the battle at the Alamo (formerly Mission San Antonio de Valero) in the spring of 1836. During the siege of the Alamo, elected representatives from the colonies met at Washington-on-the-Brazos, where on March 2, 1836, the Texas Declaration of Independence was signed. After Santa Anna's victory at the Alamo, his forces were defeated by the Texans at the Battle of San Jacinto. Because of its distance from the Mexican border and the lack of large settlements, no major battles of the Texas Revolution occurred in northcentral Texas (Tindall and Shi 1996:579-581).

\section{Republic of Texas: 1836-1846}

In 1836, the Republic of Texas government was loosely organized, there were no schools (Fehrenbach 1985:247), and most of the 40,000 residents were subsistence farmers. When the first elections were held in the new republic, an overwhelming majority voted to approve a union with 
the United States. The issue of slavery, which was heavily debated in the halls of power in the United States, however, stood in the way of this annexation for 10 years (Zinn 1995:153). The old Spanish/Mexican conventions, though, were quickly replaced with the more familiar AngloAmerican customs. The policy of disbursing land during the years of the Republic of Texas was governed by the Constitution of the Republic of Texas. There were three classes of settlers:

First Class-arrived before March 2, 1836

Heads of Household-one league (4,428 acres) and one labor (177 acres)

Single Man-one-third league

Second Class-arrived between March 2, 1836, and October 1, 1837

Heads of Household-1,280 acres

Single Man-640 acres

Third Class-arrived between October 1, 1837, and January 1, 1840

Heads of Household-640 acres

Single Man-320 acres

Each settler was responsible for locating the land (often unavailable in the county in which he resided); providing witnesses to attest to the arrival date; and paying for the survey and the filing fees. In most counties, the Board of Land Commissioners worked without delay because of the extreme importance of land to the citizens. Land was also distributed in differing amounts for military service. "Thus, it was virtually impossible, theoretically, for a Texas family to be landless" (Fehrenbach 1985:283). Later, the land laws of the state of Texas were set up in much the same way, and land also was granted preemptively, through "squatters' rights."

One of the major accomplishments of the government that would affect the development of northcentral Texas was aid for the creation of an initial transportation infrastructure. To consolidate the towns of the new republic, the Central National Road of the Republic of Texas was surveyed in 1844. The road connected San Antonio with the towns north to the Red River at the mouth of the Kiamichi River (WPA 1940:389). Until the spread of railroads in the later part of the century, roads like this were the main arteries of communication.

One of the most important urban areas to develop during the Republic of Texas period was Dallas. Although John Neely Bryan initially reconnoitered the Dallas area in 1840 to determine its suitability for a trading post, troops of the Republic of Texas had removed the Native American groups with whom he had intended to trade by the time he returned in 1842 . As a result, Bryan became determined to found a settlement in the area where downtown Dallas is today. In 1846, Bryan began collaborations with Colonel John C. McCoy, a former agent of the Texas Emigration and Land Company (TELC), to promote settlement in Dallas. The two men successfully lobbied the Texas legislature for the creation of Dallas County, and the settlement of Dallas was assigned as the county seat (McDonald 1978:10).

Although Dallas was formed in 1846, families started settling south of Dallas about 10 years earlier with the founding of towns such as Muskabe, Trinity City, Roane, and Wadeville. Rodney, a typical town of the period and area, was founded by Joshua Graham in 1834 with a land grant given to him as bounty for fighting in the Texas Revolution. That same year, Thomas Chambers was given a land grant of 35,424 acres (14335.6 ha) $22.5 \mathrm{~km}$ (14 miles) east of present- 
day Corsicana. These towns, which generally supported low-density, rural, agricultural communities, often consisted of a post office, a school, a cotton gin, and perhaps a blacksmith shop. Spring Hill was settled in 1837, but suffered setbacks after it was attacked by Kickapoo warriors. Navarro County was officially formed in 1846, named for Texas patriot Jose Antonio Navarro, and extended from the east bank of the Brazos River to the northwest corner of Limestone County and from the Trinity River to the southern border of Dallas County. The halfway point between two of the area's most prominent settlements, Porter's Bluff and Dresden, was chosen as the county seat, and named Corsicana in honor of Navarro's father's birthplace, the Isle of Corsica.

\section{American Statehood: 1846-1865}

When James Polk became President of the United States, he made a serious push to annex Texas into the Union. This expansionist policy was carried out when the U.S. Army moved troops to the Rio Grande, $241.4 \mathrm{~km}(150 \mathrm{mi})$ south of the traditional border of the Nueces River, in an obvious effort to provoke the Mexican government. After finally receiving the provocation that was politically required to go to war, the U.S. Army invaded and defeated Mexico, opening the way for the annexation of Texas (Zinn 1995:154-166).

Like many of the Southern states, the attitudes about secession before the Civil War were not uniform in Texas. The sympathies of most of the Anglo-American residents of northcentral Texas lay with the secessionist southerners. After all, a majority of them had immigrated from the South, the region as a whole had a substantial slave population, and the cash economy of the area was built on slave-based agriculture (Webb and Carroll 1952:1:306). Some counties, however, supported Sam Houston's Unionist forces during the early part of the war (McCroskey 1997).

\section{Post-Civil War: 1865-1900}

Northcentral Texas escaped serious, direct effects from the Civil War, being too far from the centers of fighting to the east and south to be affected by Union forces, and too far east of the frontier to be affected by the resurgence of Native American problems that accompanied the withdrawal of U.S. and Texas military forces (Pool 1975:110-113). The defeat of the South in 1865 brought with it the end of slavery in Texas, the breakdown of the old slave-based plantation system, and the presence of a Union army of occupation.

The end of slavery brought chiefly cosmetic changes in the economic and social landscape of northcentral Texas. Lacking the cheap and dependable labor resources provided by slavery, the large plantations of the antebellum period ceased to be economically feasible, and many were broken up and partially sold off. Most of the land put on the market found its way into the hands of speculators and investors, resulting in a new system of sharecropping or tenant farming that replaced the old plantation system. Productive land was often held by absentee landlords and the labor supplied by African-American or poor Anglo-American sharecroppers or tenants. Although this system failed to improve the economic or social status of sharecroppers and tenants, it did prove to be a successful replacement for the antebellum system and allowed for the continued disenfranchisement of poor people, no matter their race (Hillard 1990:122-126). Pelham, originally known as "Forks of the Creek," was founded in 1866 in Navarro County as a free slave town. 
Although it began as a rural, agricultural community, the town benefited by the oil boom in the 1890s. By the beginning of the twentieth century, the bulk of the rural farms in northcentral Texas were operated by sharecroppers or tenants (Elam 2002).

Although the organization of the agriculture changed slightly after the Civil War, the cash crops remained the same. There was a sharp decline in cotton production after the war; however, because of the immigration during the $1880 \mathrm{~s}$, cotton production rose to the prewar numbers and beyond (WPA 1940:76). As lumber became an increasingly important resource, some towns, such as Corsicana and Rural Shade, built steam-powered gristmills.

After 1870 , the population of northcentral Texas began to increase, and the region began to recover from the worst effects of the war and the subsequent recession. One of the most important factors in this recovery was the increasing role of the railroad in the regional economy. A small amount of railroad construction had occurred prior to the outbreak of the war, when more than $80.5 \mathrm{~km}$ ( $50 \mathrm{mi}$ ) of track had been laid westward from Texarkana in 1857 by the Memphis, El Paso, and Pacific Railroad. When railroad construction resumed four years after the Civil War ended, it continued at a relatively steady rate. Some Navarro County towns that were established in the years just prior to railway construction, for example, Kelm, King Willow, and Re, declined after they were bypassed by the railroad. Other towns, such as Corbet and Black Hills, built around train transportation, flourished. The town of Navarro relocated to be close to the railroad. Railways that passed through Navarro County included the Trinity and Brazos River, the St. Louis Southwestern, the Rock Island, the Houston and Texas Central, and the Pacific and Burlington railways.

Even more important than the railroads, Navarro County experienced the first oil boom in Texas. While drilling for water, the Corsicana Water Development Company struck oil in 1894. Oil was first shipped out of Corsicana by rail tanker in 1895, and the first refinery was built in 1897 . Production was approximately 500 barrels per day. This oil discovery was the most important find west of the Mississippi, and by 1898, 287 oil rigs were established within the city limits.

\section{Twentieth Century}

Until the beginning of World War I, northcentral Texas remained an agriculture-based region. The few major cities of Dallas, Fort Worth, Denton, and Sherman served primarily as transportation hubs to get crops and livestock to market. Beginning with the huge agricultural and industrial expansion during World War I, the urban areas began to grow and the rural areas began to alter the landscape of the region. The influx of federal monies would serve as the harbinger of the New Deal programs of the 1930s through the Cold War that would dramatically alter the economy and social landscape of northcentral Texas. As World War I began, the military established several bases in the area, facilitating the rapid development of New South cities in the mid-twentieth century (Goldfield 1982:181-184). The U.S. Army set up Camp Bowie in Fort Worth as a training installation, and the U.S. Army Air Force converted nearly all of their airfields into flight training facilities. The discovery of oil near Ranger, Texas, in 1917 contributed to a great economic boom during World War I. Navarro County experienced another oil boom with the opening of the Powell Oil Field in 1923. Because of the agricultural nature of the area's economy, the Great Depression was just the culmination of problems that had appeared after World War I. New Deal programs such as the Civil Conservation Corps performed agricultural terracing and soil conservation in the counties. The establishment of co-ops 
accomplished rural electrification. The WPA and other agencies paved roads and constructed all manner of institutional buildings (i.e., schools, city halls, courthouses, etc.) across the state. A flight training center was opened in Corsicana by the Air Activities of Texas in 1942. Construction of Navarro Mills Lake began in 1959, with the damming of the Trinity River.

By 1970, however, Navarro County was experiencing an increase in population, manufacturing, and agricultural production. The primary crops are oats, wheat, hay, sorghum, and cotton. Numerous vegetables, including sweet potatoes and peaches and pecans, are also raised. The manufacturing industry encompasses oil and gas production, canning and food preservation, meat packing, rubber products, and oil machinery. 


\title{
CHAPTER 4 RESEARCH DESIGN AND METHODOLOGY
}

\begin{abstract}
RESEARCH DESIGN
Project researchers developed the research design and survey methodology based on information gleaned from all available resources. Topographic, soils, and geological maps were employed to identify areas of appropriate geological and sedimentary context for intact cultural deposits. The Texas Archeological Atlas and the Texas Archeological Research Laboratory (TARL) were consulted to determine if any previously recorded sites were located in or near the project area. No sites were located within a 3.2-km (2-mi) radius of the project area.

Because these investigations were undertaken only during the final phase of the levee repairs, the project consisted of two phases: (1) monitor the ongoing excavations from one borrow area and the redistribution of fill soils to a repair location (see Figures 2 and 3); and (2) visually inspect the sites of five completed repairs and their borrow areas. The goal of the visual inspection was to determine if cultural materials were visible on the surface of the disturbances and, if present, the extent and content of such materials. During the ongoing excavations and repair, the goal of the archeological monitoring was to determine the presence, and evaluate the significance, of any intact archeological deposits.
\end{abstract}

Significant prehistoric archeological sites dating to the Middle and Late Archaic periods are known to exist along Chambers Creek, located $88.5 \mathrm{~m}(0.55 \mathrm{mi})$ from the western-most point of the project area and less than $161 \mathrm{~m}(0.10 \mathrm{mi})$ from Cummins Creek. Therefore, the project area would normally be considered to possess a high probability for containing deeply buried prehistoric cultural deposits. A high degree of prior disturbance in the way of creek channelization, and levee and railroad construction, however, significantly downgrades the probability of finding intact deposits. It should also be noted that at the point where Chambers Creek is closest to the project area, the channelization of the creek begins north of the original channel, increasing the distance to Chambers Creek for most of the project area. 


\section{METHODOLOGY}

\section{Archival Research}

The project archeologist conducted archival research in order to gather data that would be used to guide the development of the monitoring methodology. Site files maintained by TARL indicated that no archeological sites are located within $3.22 \mathrm{~km}(2.0 \mathrm{mi})$ of the project area. For geological information, a variety of sources, including The Bureau of Economic Geology, Dallas Sheet, and Soil Survey of Navarro County, Texas (Meade et al. 1974), was examined for soils information. A literature survey of Navarro County archeology, prehistory, and history was conducted using sources located in the Geo-Marine library. The results of this research were used to guide the field methods and to identify areas with the highest probability, as well as those with the lowest probability, to retain archeological deposits. These data served as a contextual framework so that any newly recorded sites could be evaluated for significance.

\section{Fieldwork}

A total of one person-day was expended during the archeological monitoring in Navarro County. Fieldwork consisted of archeological monitoring of ongoing work and a thorough visual inspection of completed repair locations. The repair work entailed gathering fill soil with a backhoe from a borrow area and transferring it to a truck, which then transported the fill to LR 2. Once the fill was dumped, a small bulldozer was used to spread the fill out and level it. Monitoring consisted of visually inspecting the borrow area after the backhoe gathered each load of soil, and then inspecting the soil while it was being spread out. Because visual inspection was the sole method of investigation at the completed repair locations, transects were made at 5-m intervals. Observations as to the extent of disturbances, soil types, and vegetation were recorded.

Daily field notes detailing the investigations and field observations were kept by the project archeologist. Digital photographs were taken to record the general topography, vegetation, disturbances, and urbanized development of the project area, as well as the activities related to the cultural resources investigations. The project archeologist maintained a log of all photographs taken during the project. 


\section{CHAPTER 5 RESULTS OF INVESTIGATIONS}

The project area is located south of the town of Rice, in Navarro County, Texas, in the flood plain of Cummins Creek, which flows into the Waxahachie Slough and eventually into Chambers Creek, a major tributary of Richland Creek and the middle Trinity River (see Figure 2). A levee, adjacent to the right bank of a channelized portion of Cummins Creek and the western side of the Southern Pacific Railroad, had washed out in various locations due to frequent flooding (Figures 3 and 4). Archeological investigations were conducted at the levee repair sites and consisted of 5 hours of observing borrow and fill activity at two locations and visually inspecting seven areas of previously repaired and disturbed locations. A total of seven borrow and repair areas along the levee had been either opened or repaired prior to the commencement of the archeological monitoring and comprised approximately 0.87 ha $(2.15 \mathrm{ac})$. Repairs to six of these areas, which included raking and grading land in order to drain standing water, and opening borrow areas to provide clay fill soils, affected a section $1.29 \mathrm{~km}(0.8 \mathrm{mi})$ long. Archeological monitoring was undertaken at repair and borrow areas totaling $0.18 \mathrm{ha}(0.45 \mathrm{ac})$. The site foreman estimated that disturbances in the borrow areas were less than $1 \mathrm{~m}$ deep, but disturbances down to $1.5 \mathrm{~m}(4.92 \mathrm{ft})$ below surface were observed.

In the area of the repairs, the levee is bracket-shaped. A short, 60.96-m (200-ft) leg extending west-to-east lies on the right bank of a channelized portion of Cummins Creek (Figure 5; see Figure 3). The levee then turns south, paralleling the Southern Pacific Railroad to the east for $670.56 \mathrm{~m}(2,200 \mathrm{ft}$; Figure 6). At this point, the levee continues south to Chambers Creek, and also intersects with an east-to-west section of a double levee (Figures 7 and 8). The project follows the double levee westward for $731.52 \mathrm{~m}(2,400 \mathrm{ft})$. Fields planted in grass are adjacent to the western side of the levee (Figure 9). A long borrow area lies between the eastern side of the levee and the western side of the railroad (Figure 10). Levees, railroad berms, and adjacent areas planted in grass were mowed and maintained in order to improve soil retention. The 1961 U.S. Geological Survey (USGS) Chatfield quadrangle topographic map indicates long, wet areas on both sides of the levee that likely represent borrow areas from previous episodes of levee and track construction (Figure 11; see Figure 2). 


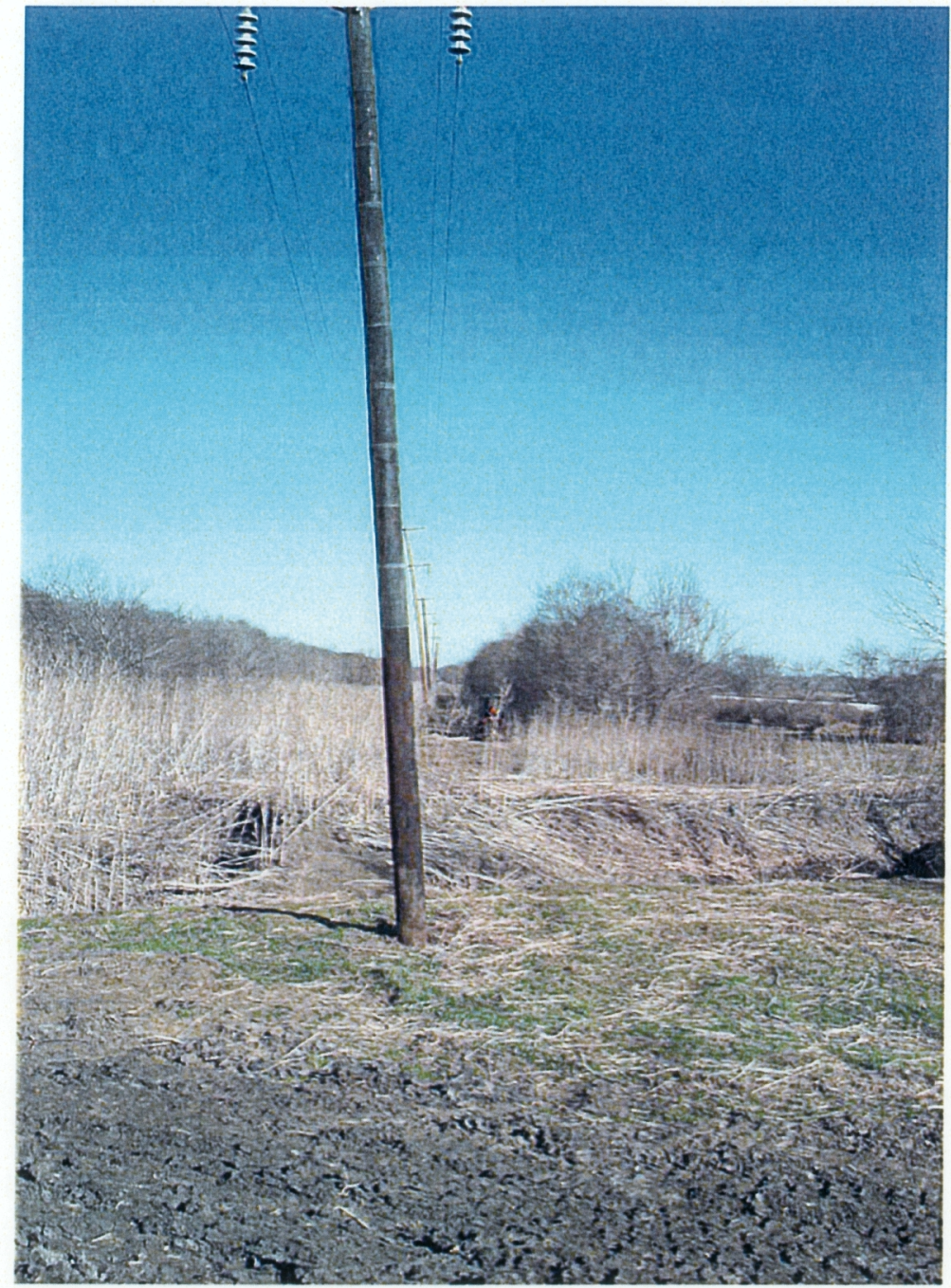

Figure 3. View of channelized portion of Cummins Creek (facing north).

At the time that Geo-Marine began the archeological monitoring process, five of the seven levee repair areas had already been repaired. Investigations at these five locations involved a thorough visual inspection, photographic records, and written notes. Because no invasive testing would be conducted at these locations, visual inspection was conducted at 5-m intervals.

\section{VISUAL INSPECTION}

The levee is fairly uniform throughout the project area, measuring approximately $9.14 \mathrm{~m} \mathrm{(30} \mathrm{ft)}$ wide at the base and $3.66 \mathrm{~m}(12 \mathrm{ft})$ high. LR 1 consists of the $45.72-\mathrm{m}(150-\mathrm{ft})$ west-east segment just south of Cummins Creek, before the levee turns south. Substantial repairs to this portion were made by taking borrow dirt from BAs 1 and 2. Visual inspection revealed clusters of animal bone at the base of the levee. The low-density remains consisted of large, bleached fragments of large mammal and turtle bone scattered over a $40-\mathrm{x}-1-\mathrm{m}$ area. Closer inspection of these fragments, 


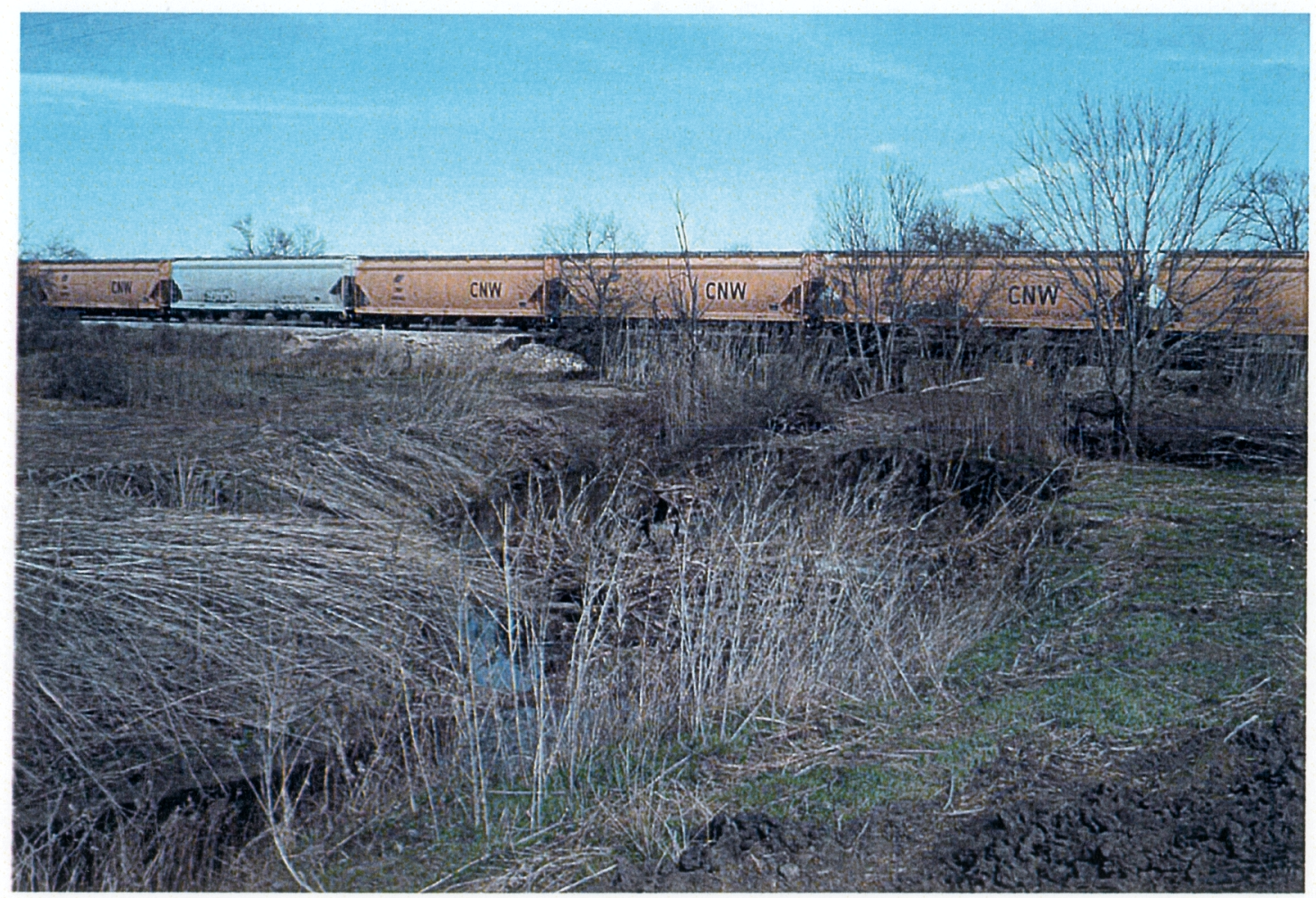

Figure 4. View of Cummins Creek and Southern Pacific Railroad (facing east).

however, revealed that the remains were fairly new; tissue and hair adhered to some surfaces, and all fragments were still exuding grease. None of the fragments exhibited spiral fractures or any other evidence of human use or modification. These remains were not deemed to be related to either prehistoric or historic human activity.

Visual inspections at repair locations LR 2 and 4 through 7 failed to reveal the presence of cultural deposits. Ground visibility in each of these locations was 100 percent. Silty clay soil with numerous limestone inclusions varied in color from light gray (10YR 1/7 at LR 2) to very dark grayish brown (10YR3/2 at LRs 3 and 4). Soils appeared to be homogeneous at each

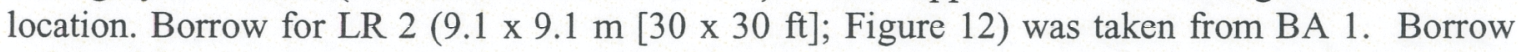
soil for LR 4 (45.7 x 27.4 m [150 x 90 ft]; Figures 13 and 14) was taken from the adjacent field on the north side of the levee. Borrow soil for LR 5 ( $45.7 \times 45.7 \mathrm{~m}[150 \times 150 \mathrm{ft}])$ was taken from the adjacent field on the north side of the levee (Figure 15) and from between the two levees (Figure 16). Borrow soil for LR 6 (15.2 x $15.2 \mathrm{~m} \mathrm{[50 \times} 50 \mathrm{ft}]$; Figure 17) and LR 7 (45.7 x 45.7 $\mathrm{m}$ [150 x 150]; Figures 18 and 19), however, was taken from the slough bottoms between the levees. No evidence of cultural materials was apparent in any of the five repair locations. 


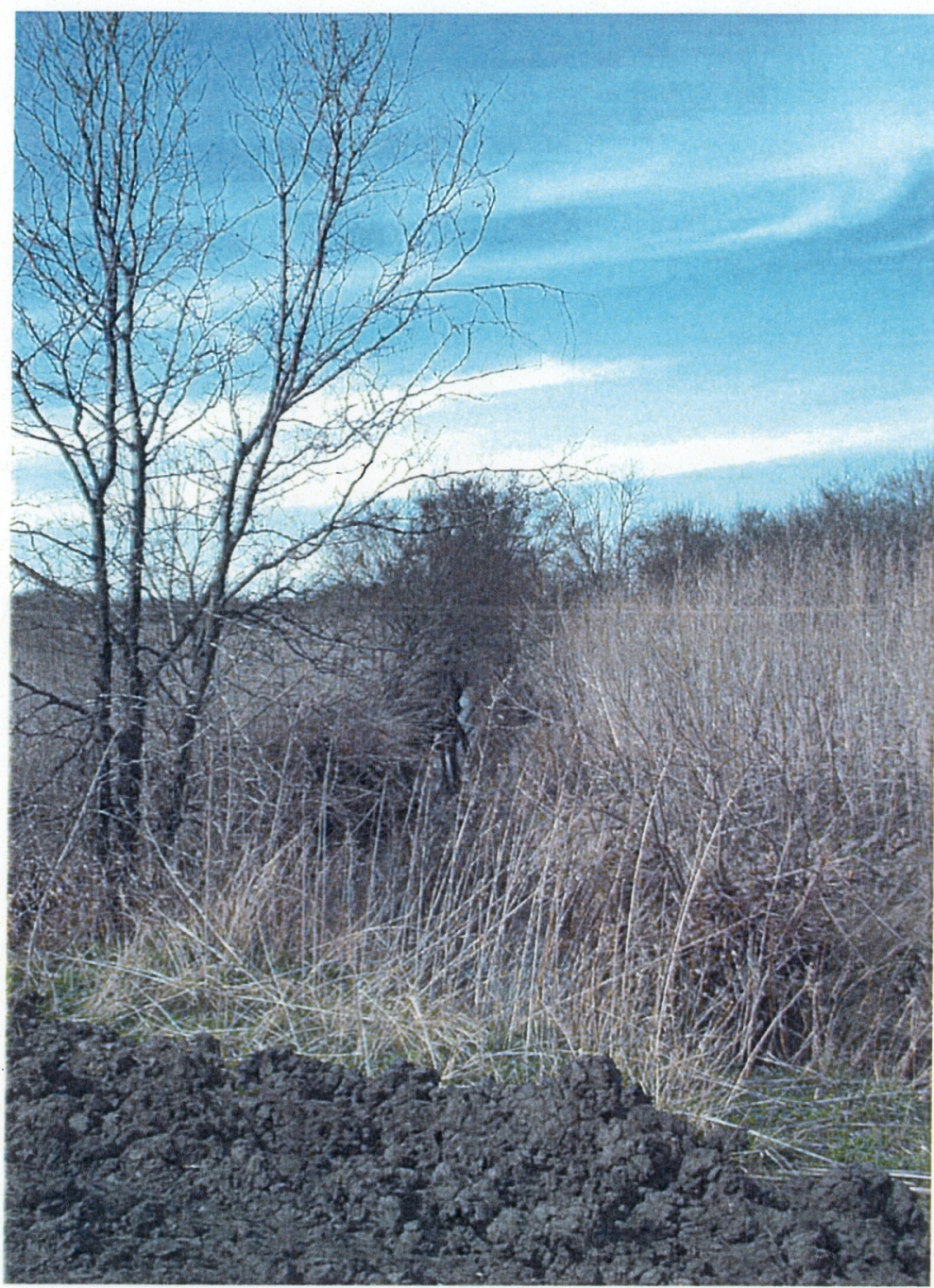

Figure 5. Channelized portion of Cummins Creek; levee is in the foreground (facing northwest).

\section{ARCHEOLOGICAL MONITORING}

Archeological monitoring was undertaken for the duration of the repairs at LR 3, which was 5 hours. Before work commenced, the extent of repairs at LR 3 and the open pit at BA 2 were visually inspected along 5-m intervals (Figure 20). The repair work entailed gathering fill soil with a backhoe from the borrow area and transferring it to a truck, which transported the fill to LR 3. Once the fill was dumped, a small bulldozer was used to spread the fill out and level it. Monitoring consisted of visually inspecting the borrow area after the backhoe gathered each load of soil, and then inspecting the soil while it was being spread out.

This activity resulted in an exposed area of $121.92 \times 15.24 \mathrm{~m}(400 \times 50 \mathrm{ft})$, with a maximum depth of $1.5 \mathrm{~m}(4.92 \mathrm{ft}$ ) in the center (Figure 21). A profile of the borrow area wall (Figure 22) revealed wet, silty clay with a very dark gray (10YR 3/1) dark, organic zone at the surface $(0-20$ centimeters below surface [cm bs]). This is underlain by dark gray $(10 \mathrm{YR} 4 / 1)$ wet silty clay 

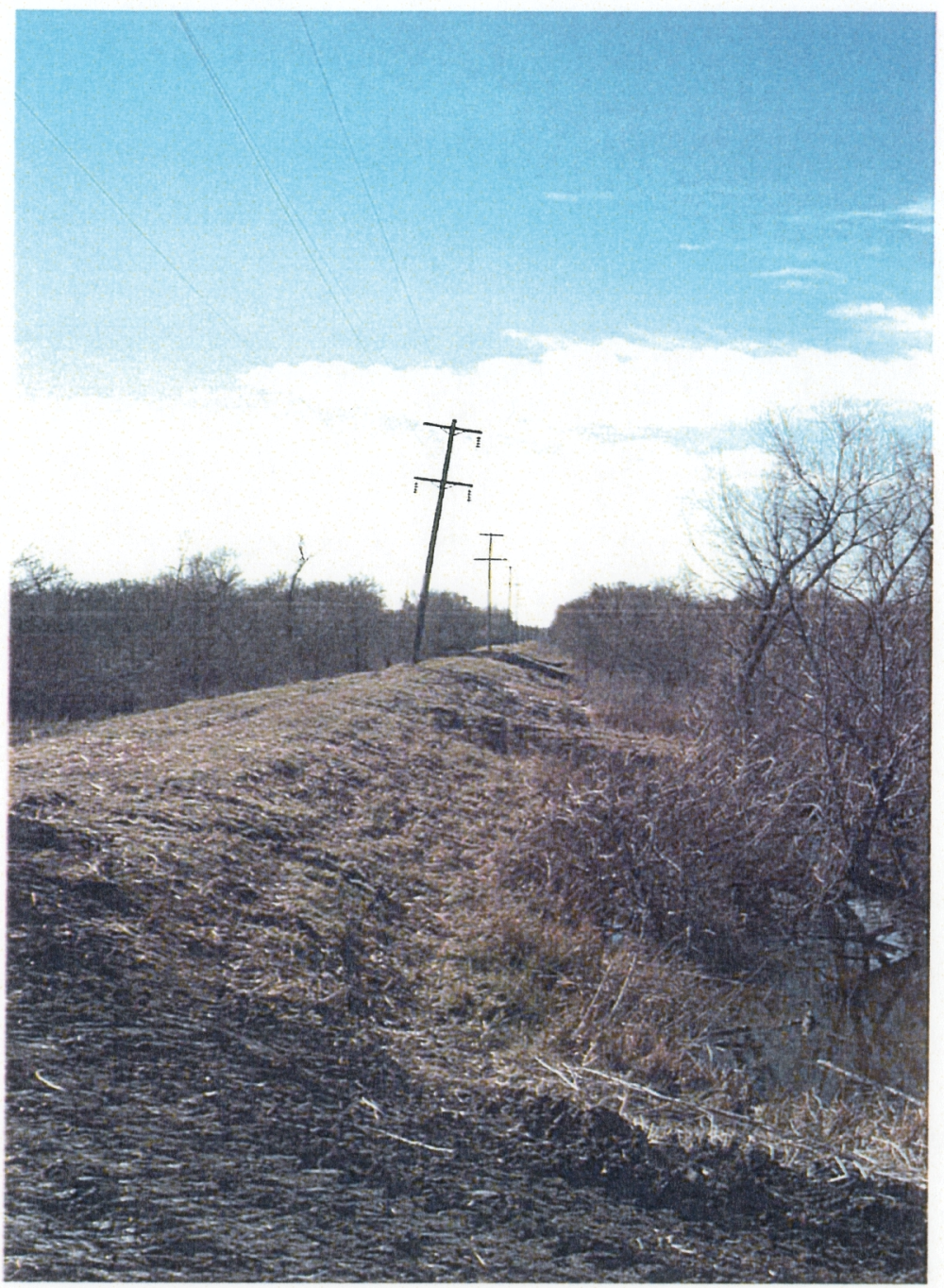

Figure 6. View of the levee parallel to the Southern Pacific Railroad (facing south).

extending to $80 \mathrm{~cm}$ bs. Below that layer is a very dark grayish brown (10YR 3/2) silty clay to $120 \mathrm{~cm}$ bs. No cultural deposits were observed during the operations that were monitored (Figure 23).

Because significant prehistoric archeological sites dating to the Middle and Late Archaic periods are known to exist along Chambers Creek, the project area would normally be considered to possess a high probability for containing deeply buried prehistoric cultural deposits. However, a high degree of prior disturbance in the way of creek channelization, and levee and railroad construction, however, significantly downgraded the probability of finding intact deposits. In fact, neither the archeological monitoring nor the visual inspection revealed the presence of either prehistoric or historic cultural deposits. Geo-Marine, therefore, does not recommend any further cultural resources investigations in this project area. 


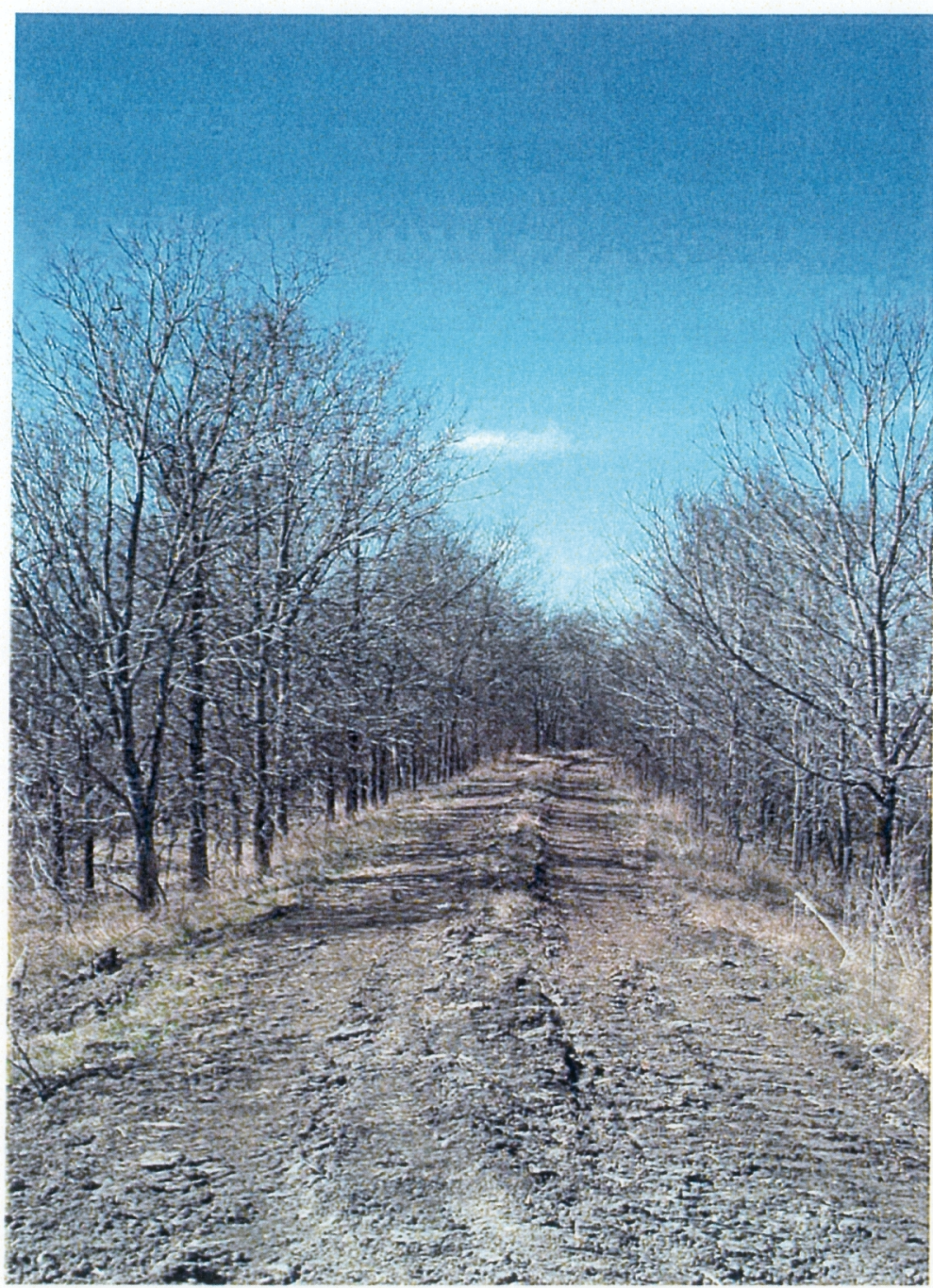

Figure 7. View of the northern double levee (facing west). 


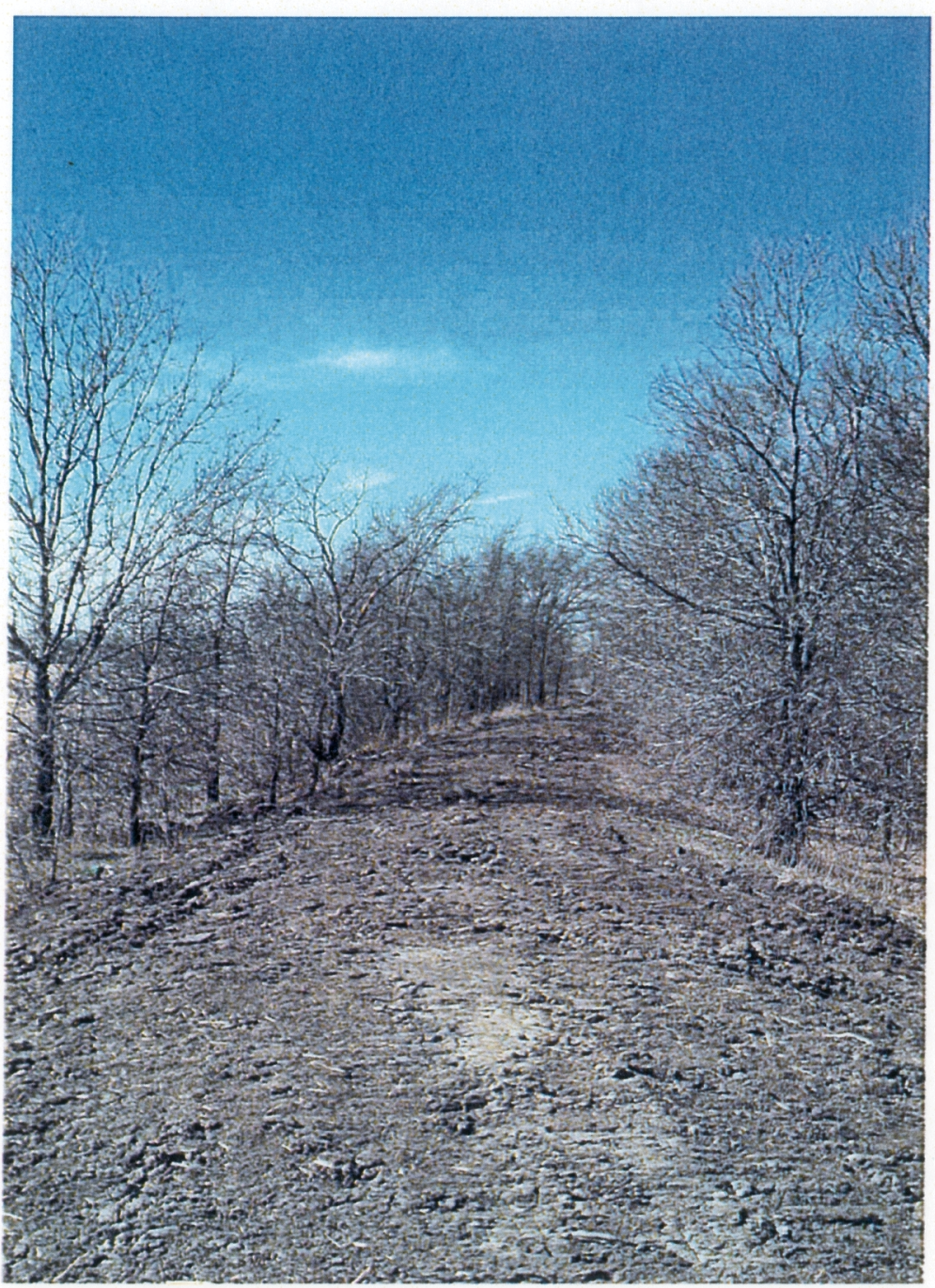

Figure 8. View of the southern double levee (facing west). 


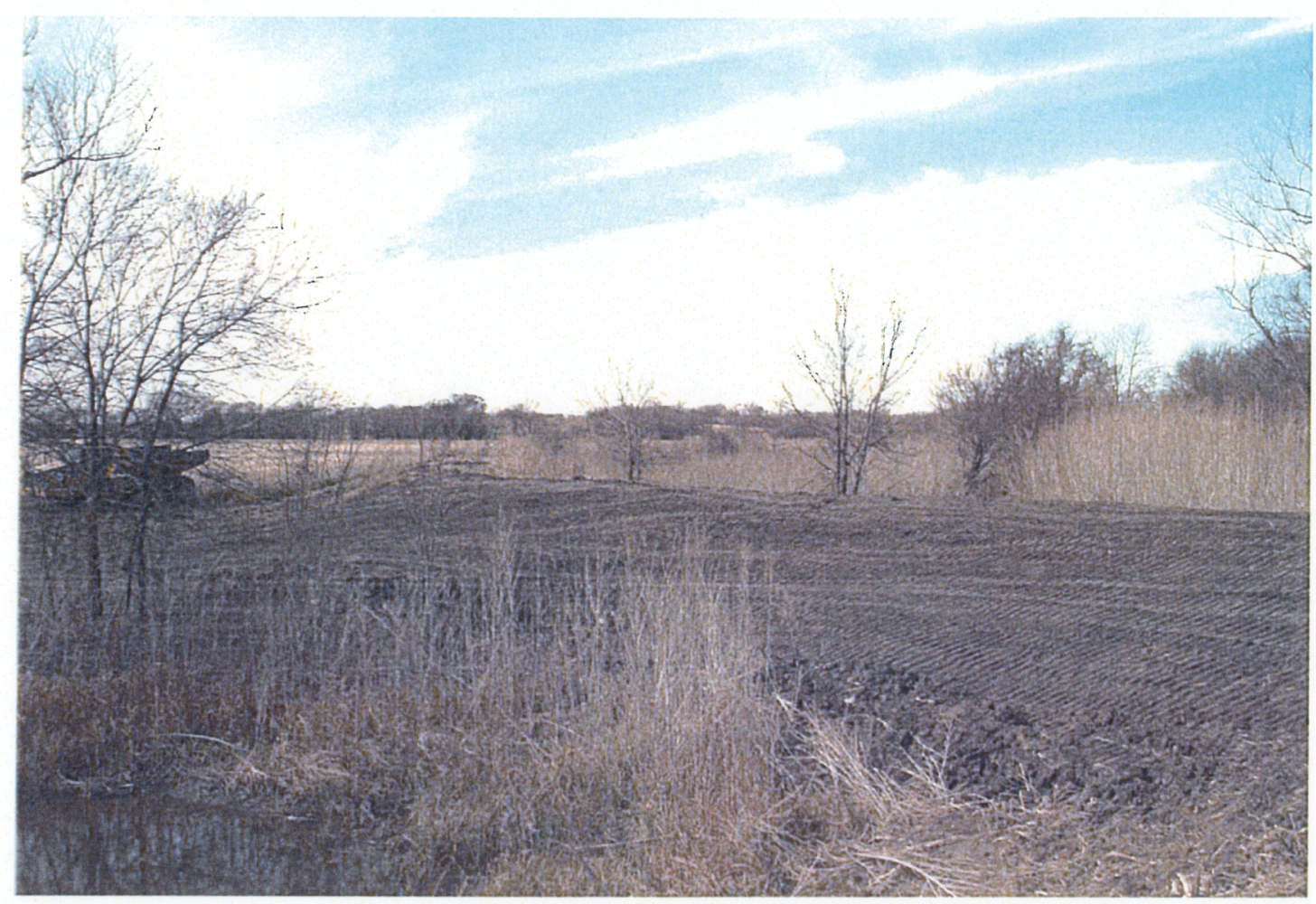

Figure 9. View of LR 1 looking southwesterly towards the Old Channel (facing southwest). 


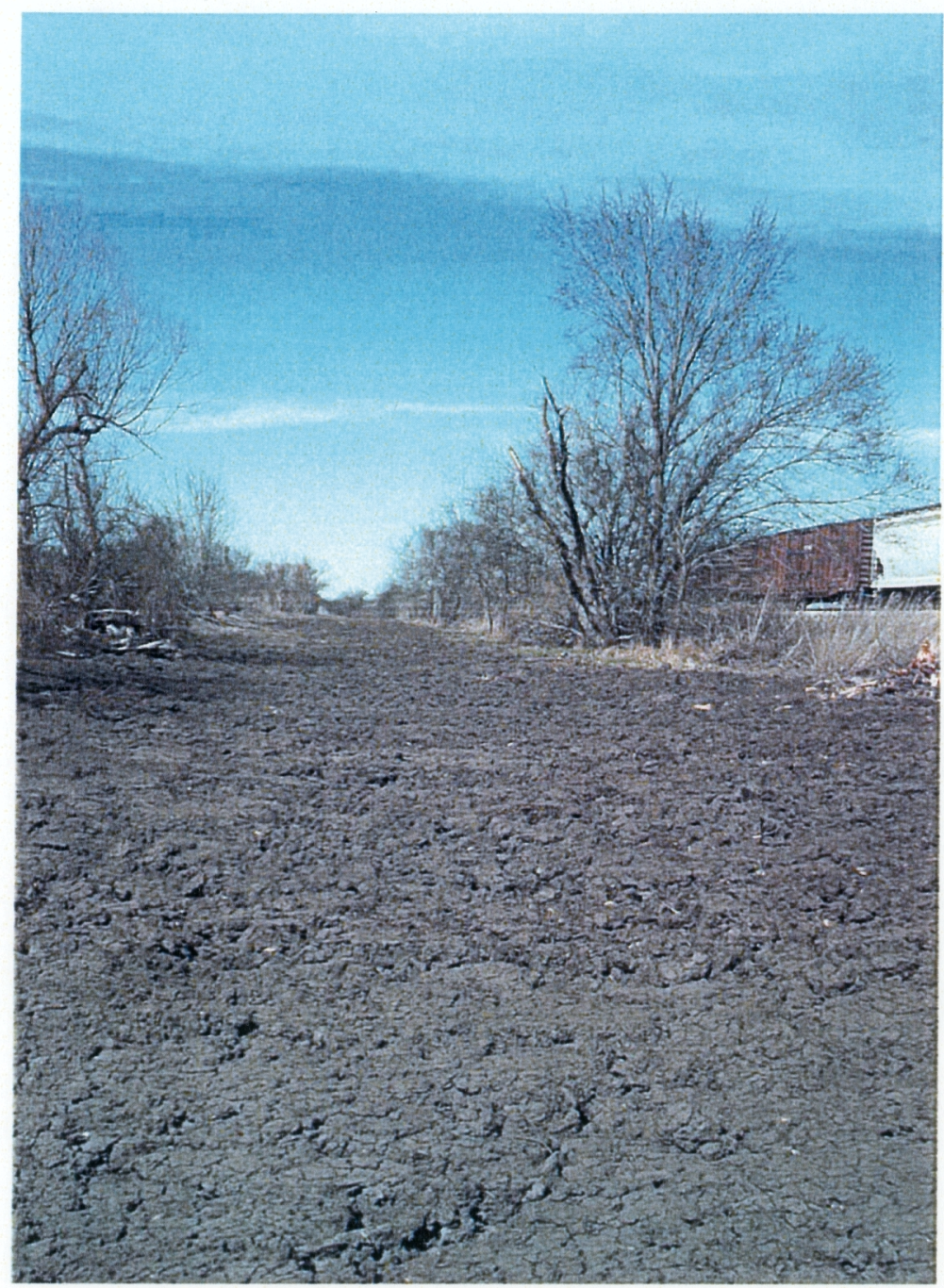

Figure 10. View of BA 1 located between the railroad berm and the levee (facing south). 


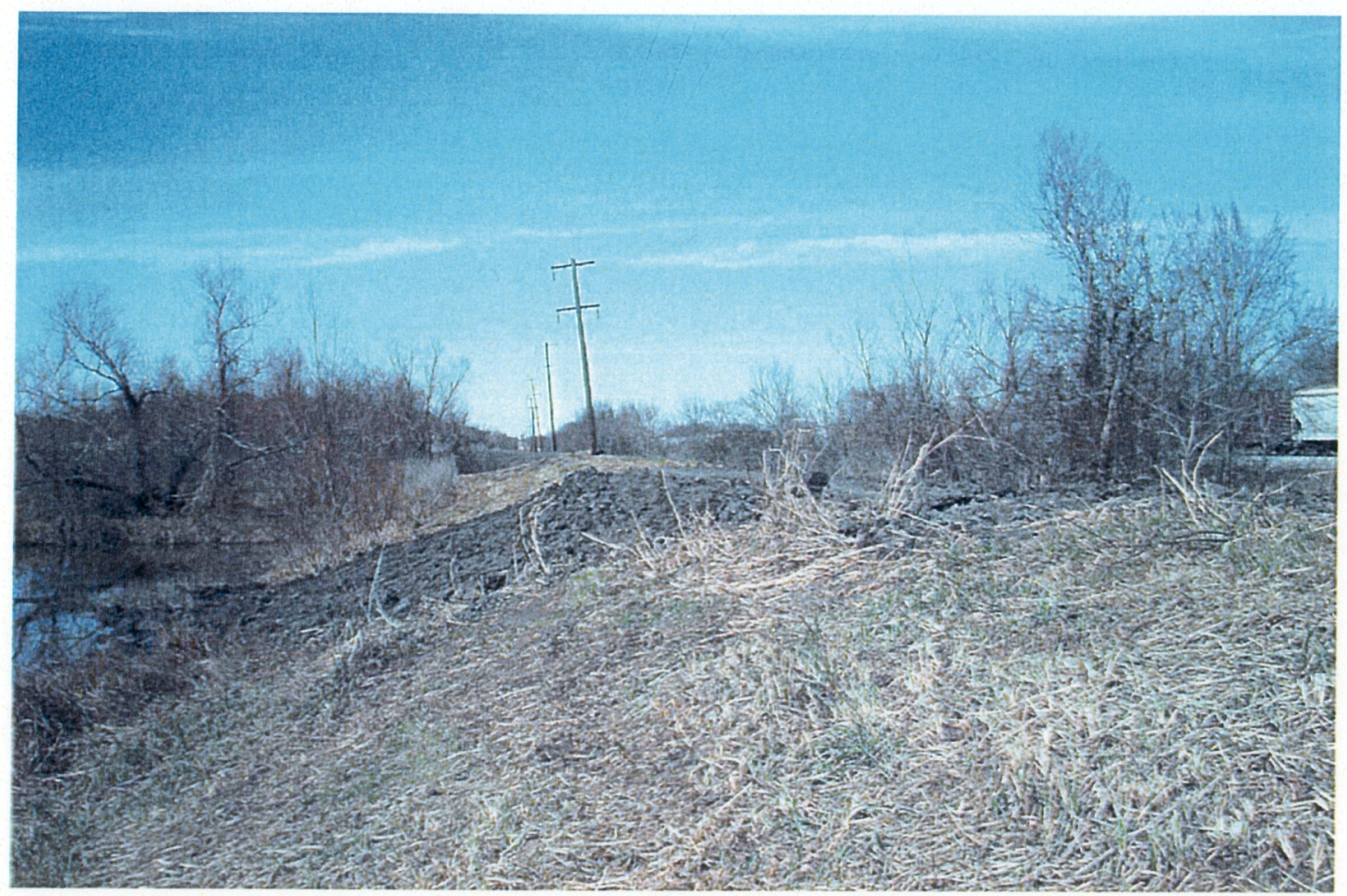

Figure 11. View of LR 2 adjacent to standing water (facing north). 


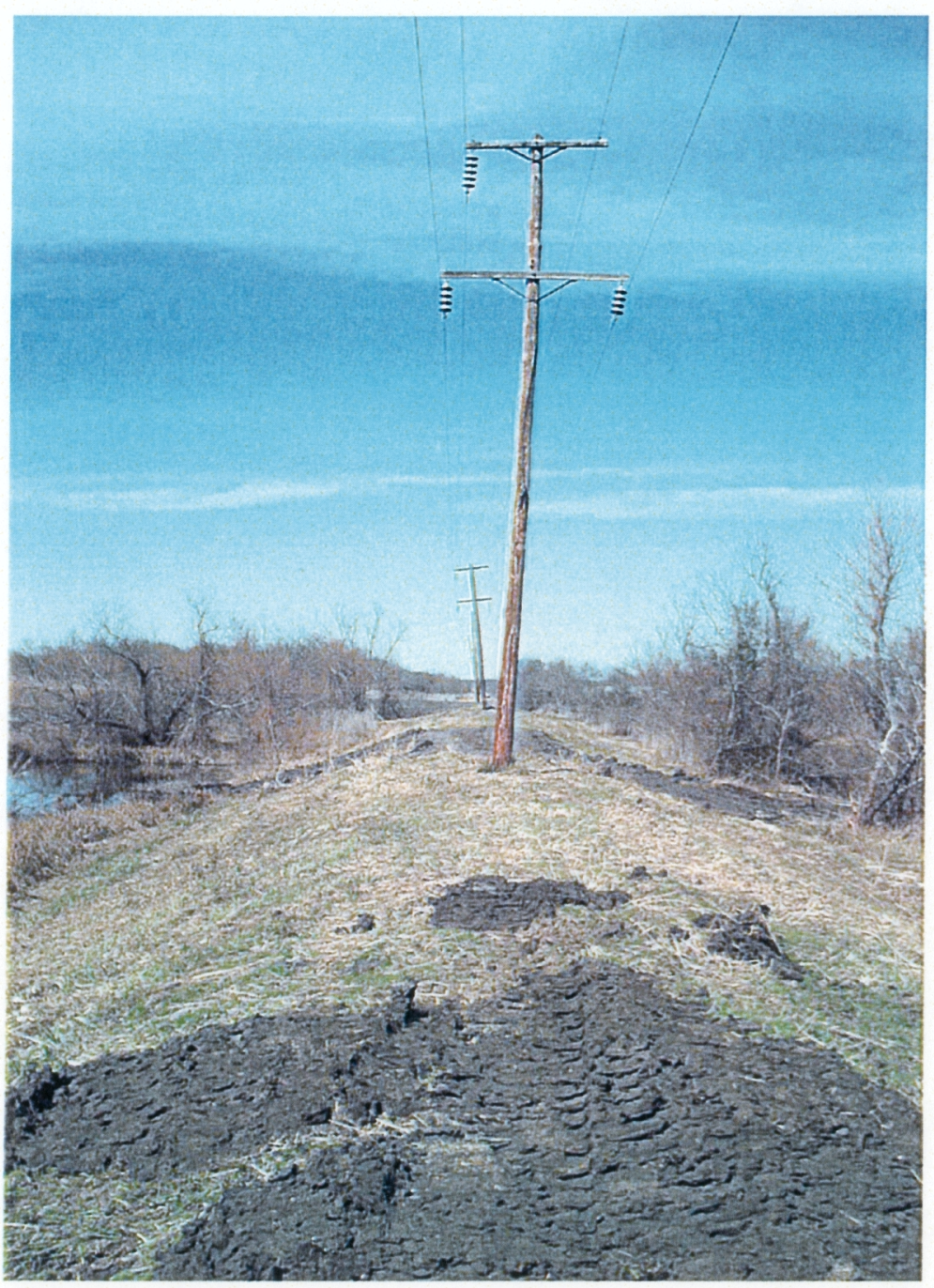

Figure 12. View of LR 1, 2, and 3 (facing north). 


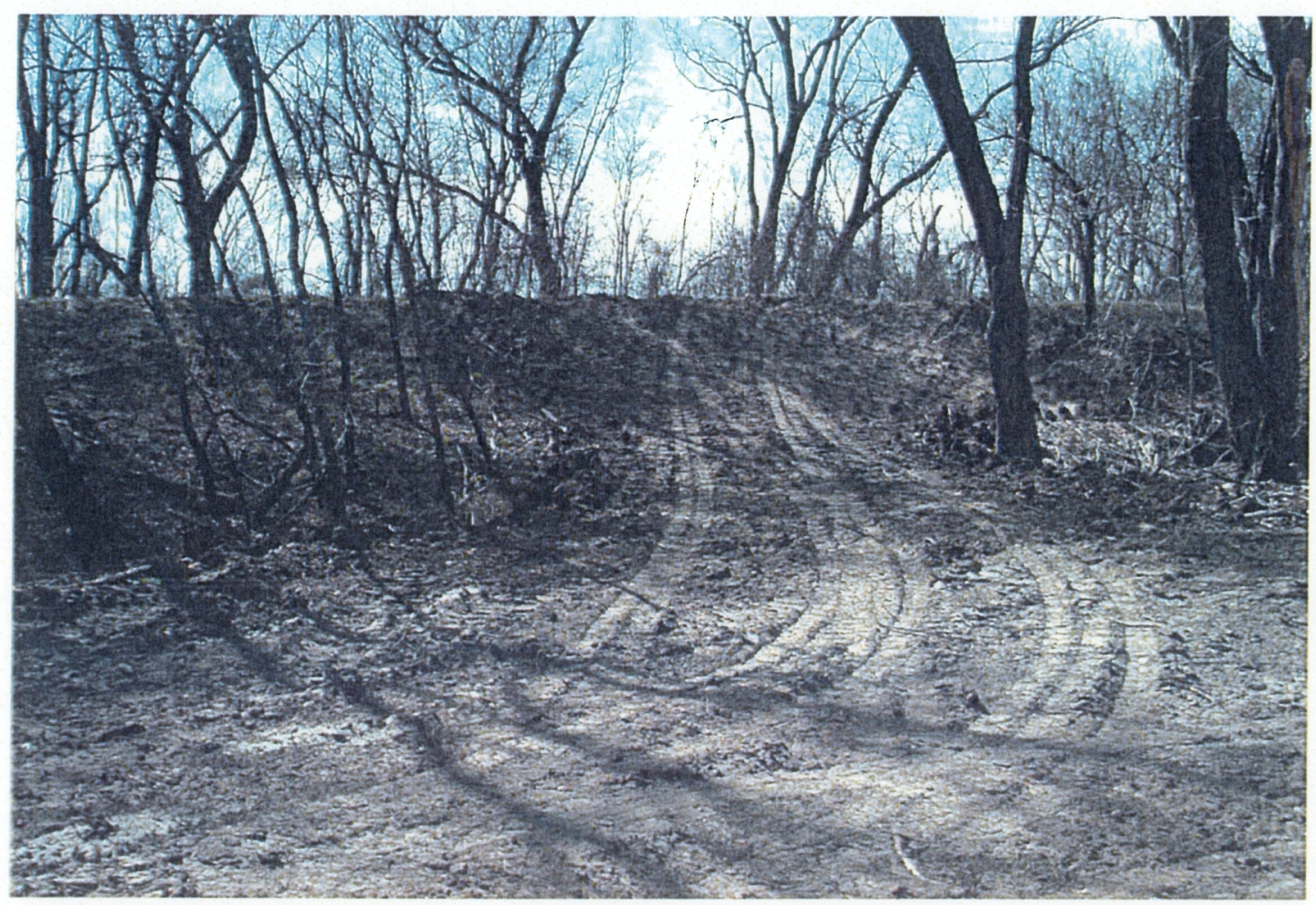

Figure 13. View of LR 4 (facing south). 


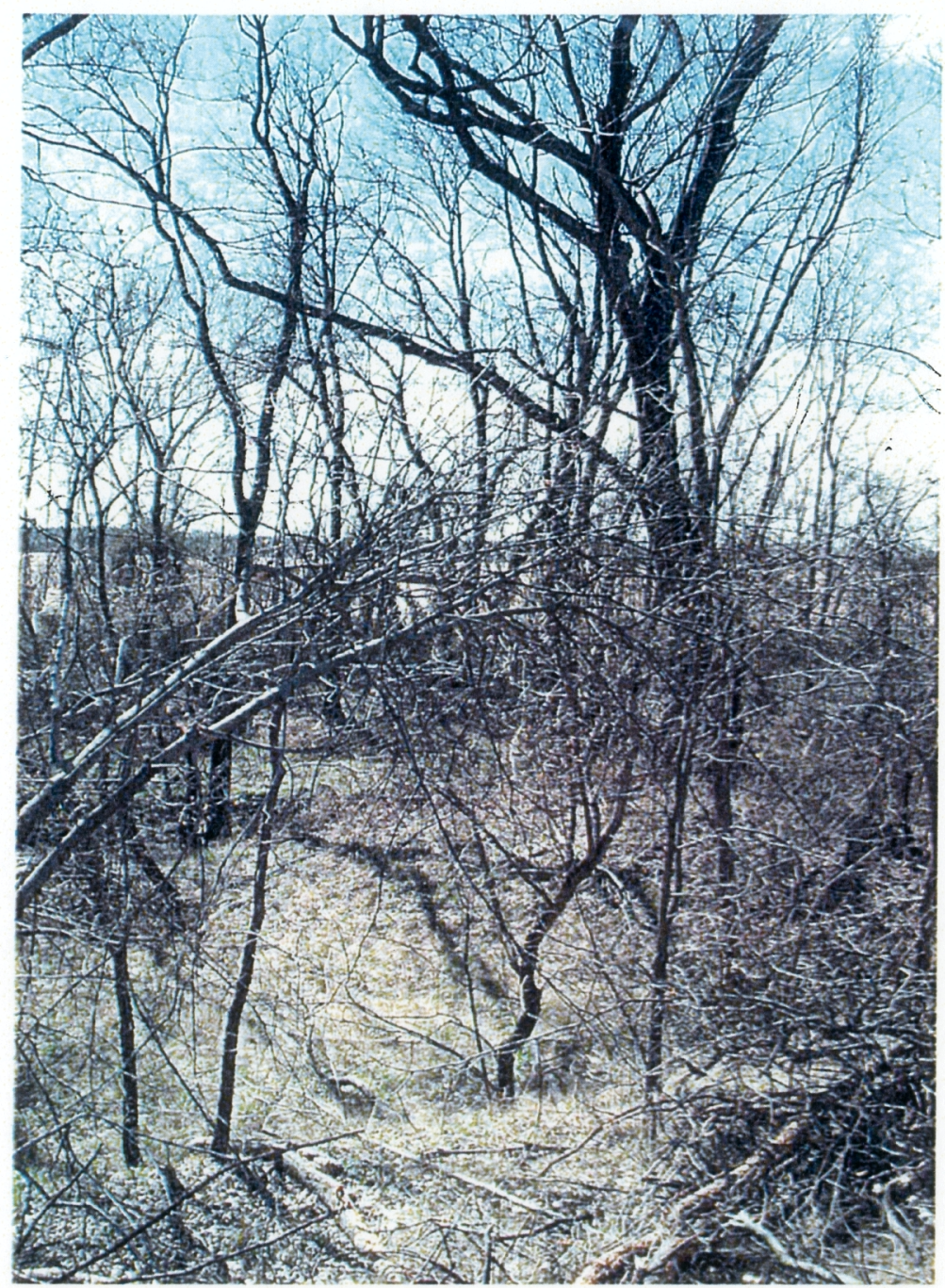

Figure 14. View of vegetation at LR 4 (facing southwest). 


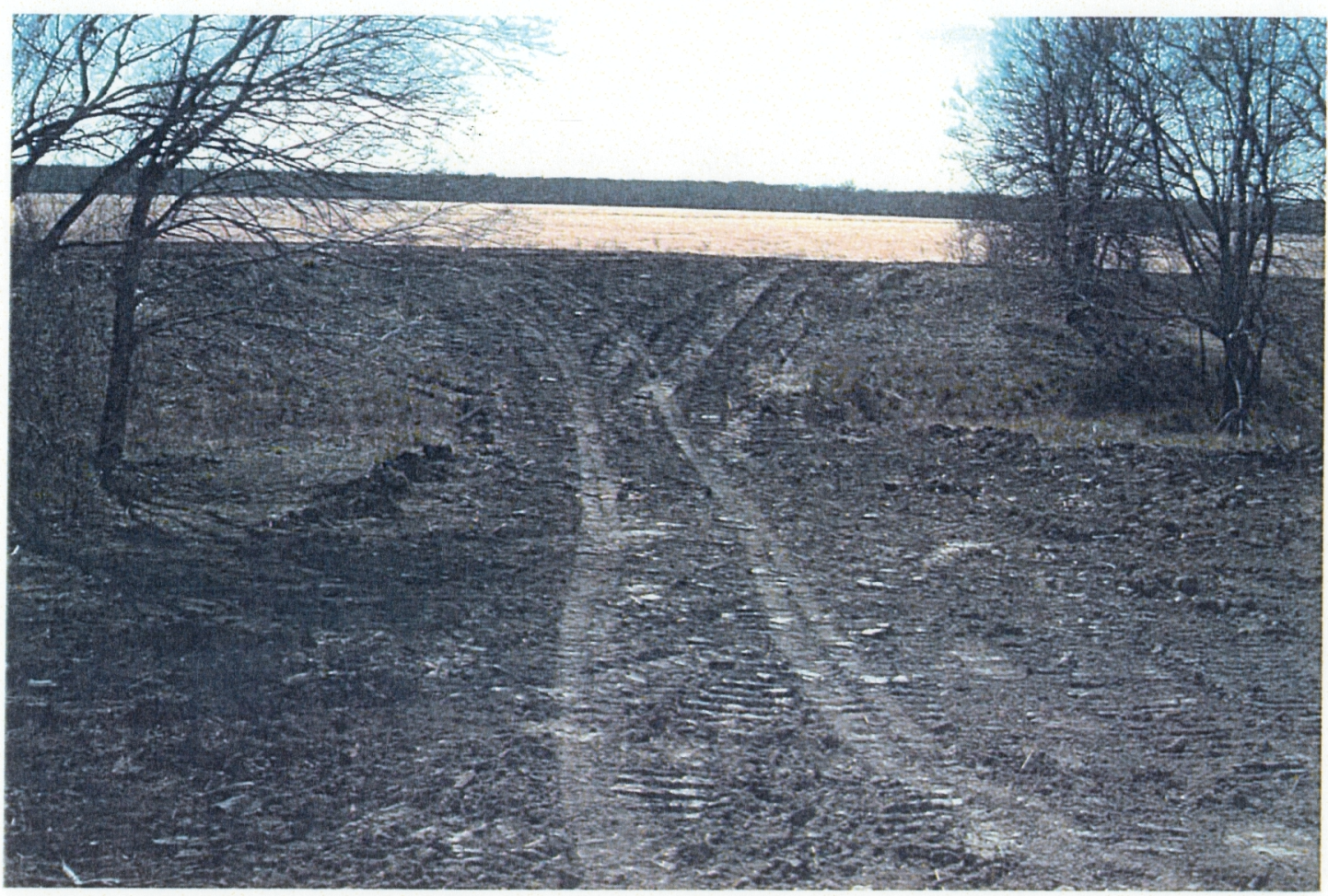

Figure 15. View of LR 5 (facing south).

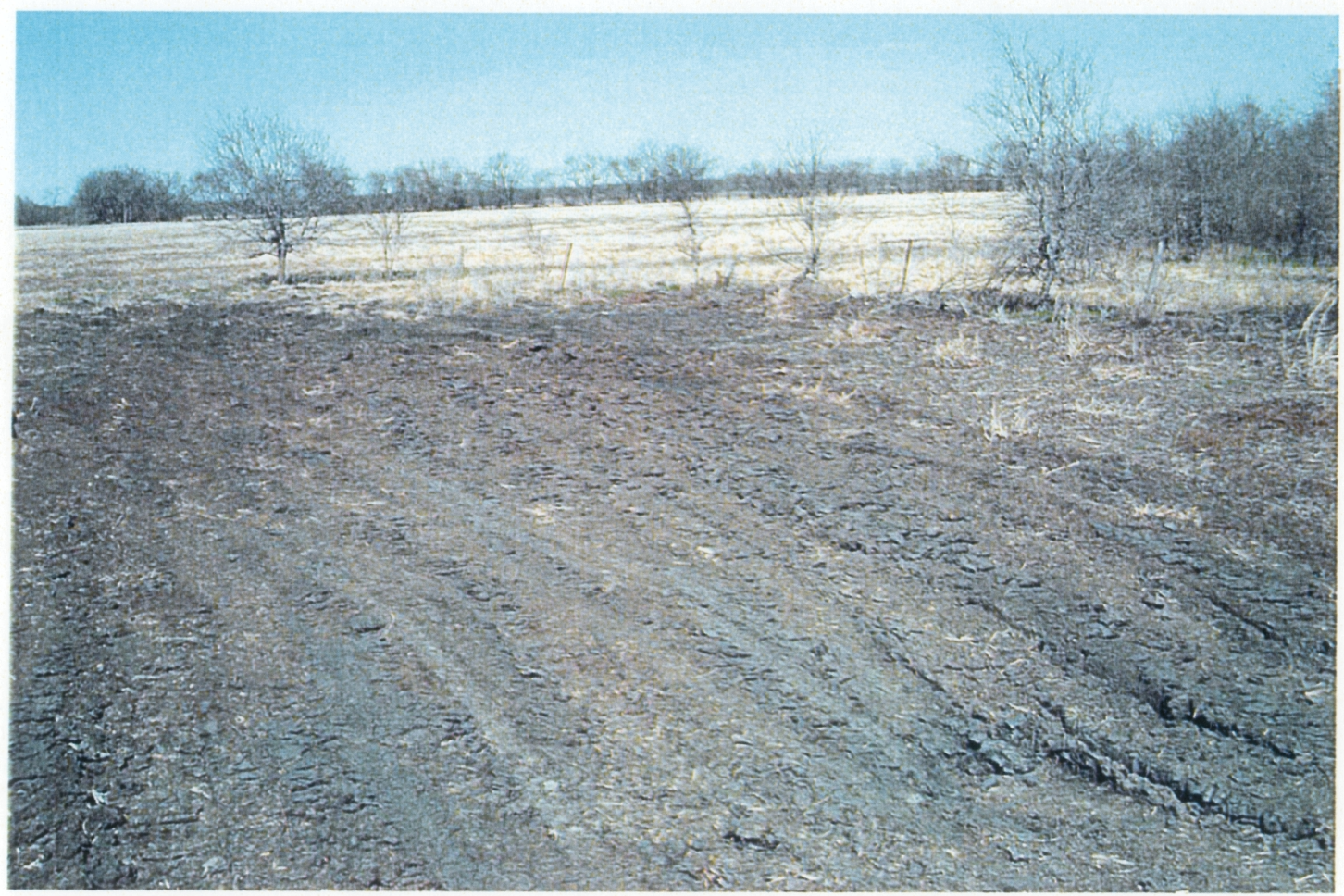

Figure 16. View of borrow area located adjacent to and north of the levee at LR 5 (facing northeast). 


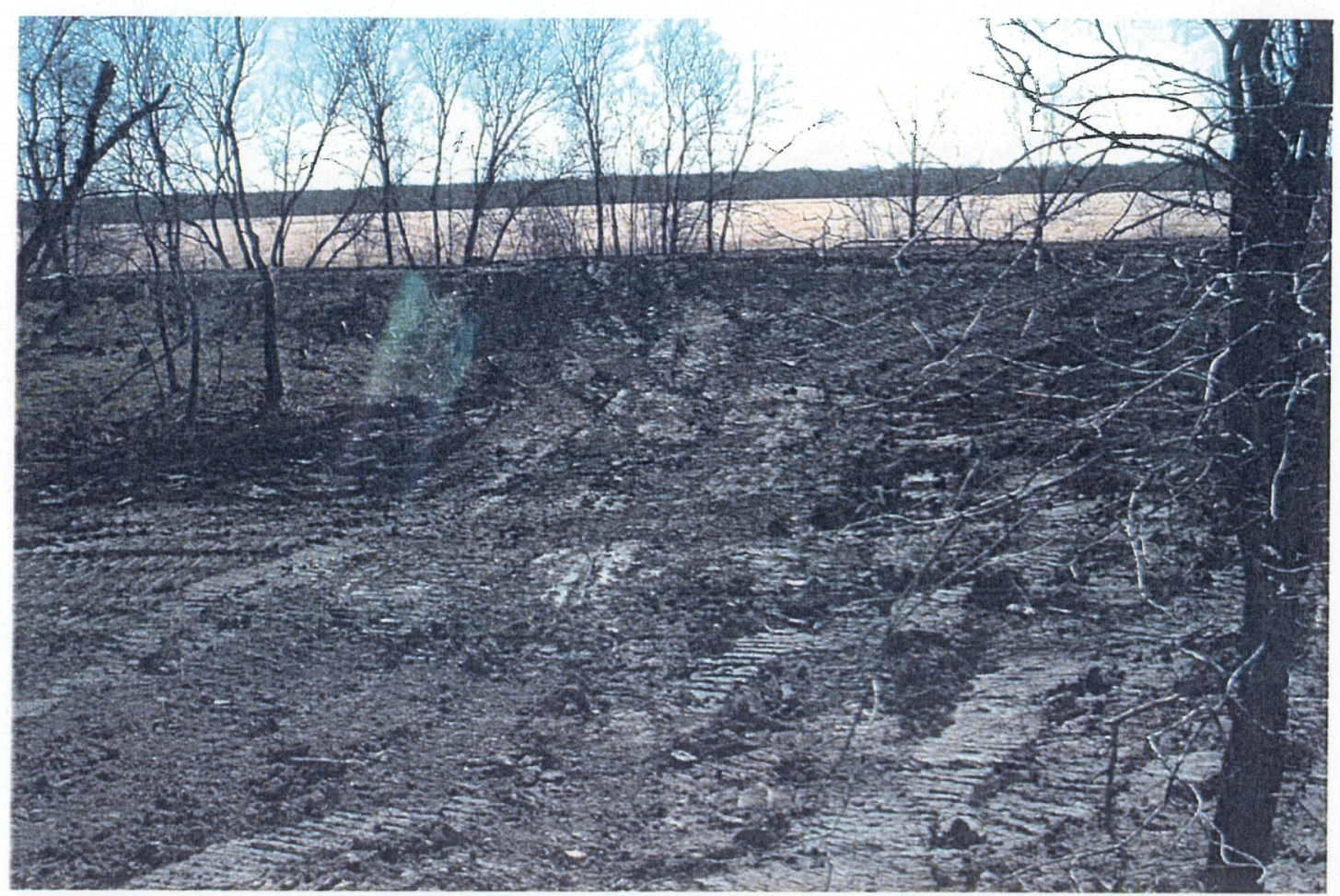

Figure 17. View of LR 6 (facing south).

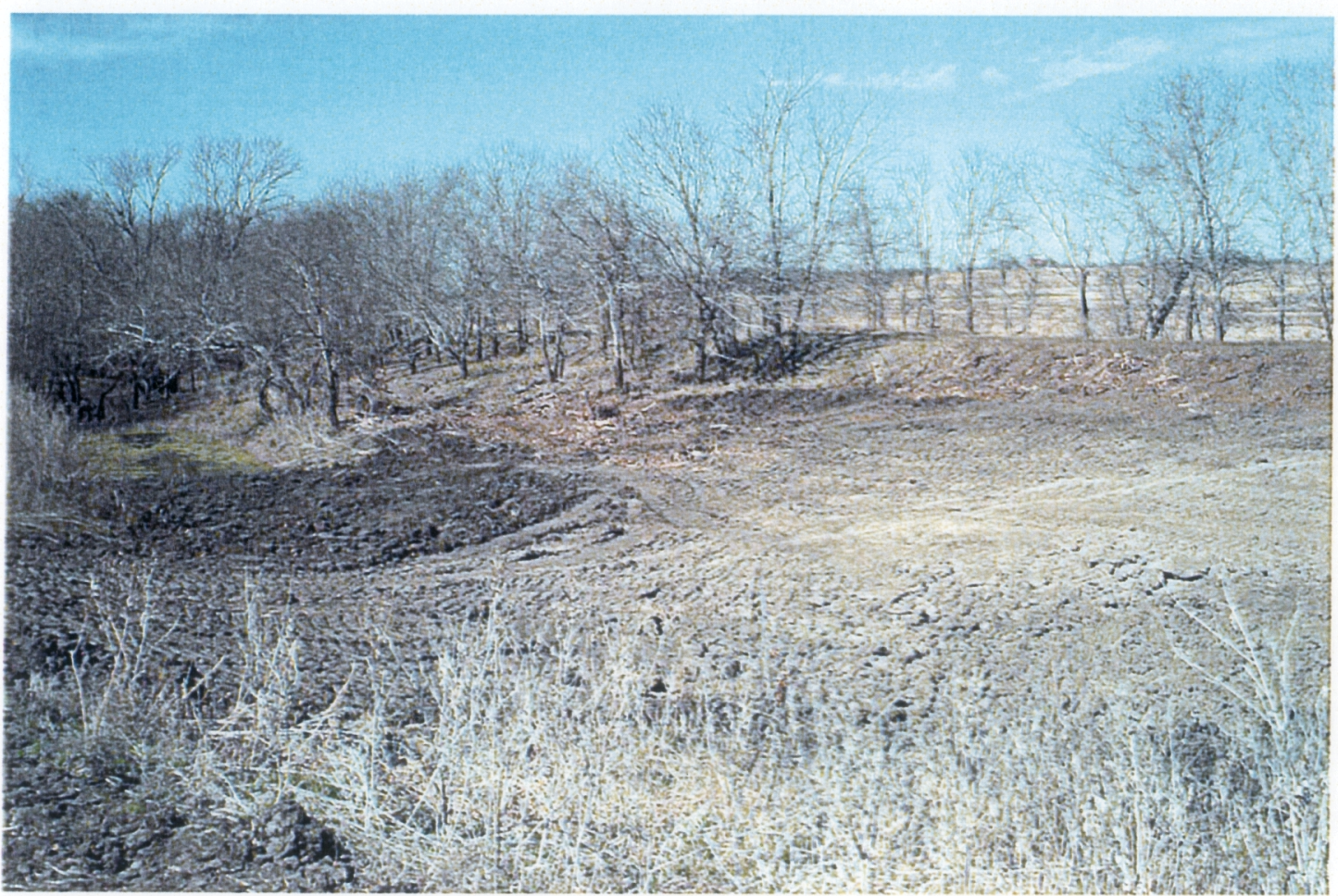

Figure 18. View of LR 7 (facing northwest). 


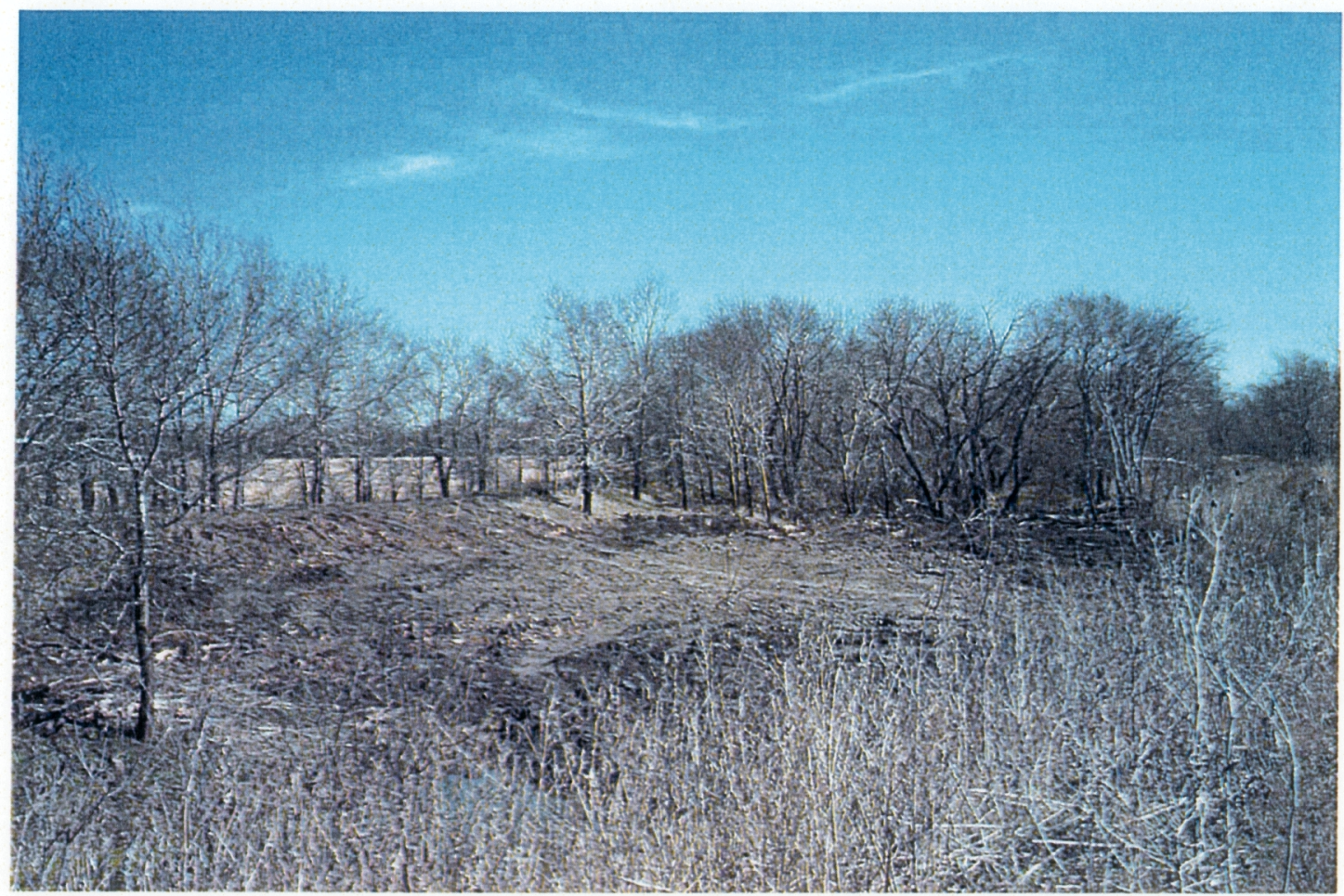

Figure 19. View of LR 7 (facing northeast).

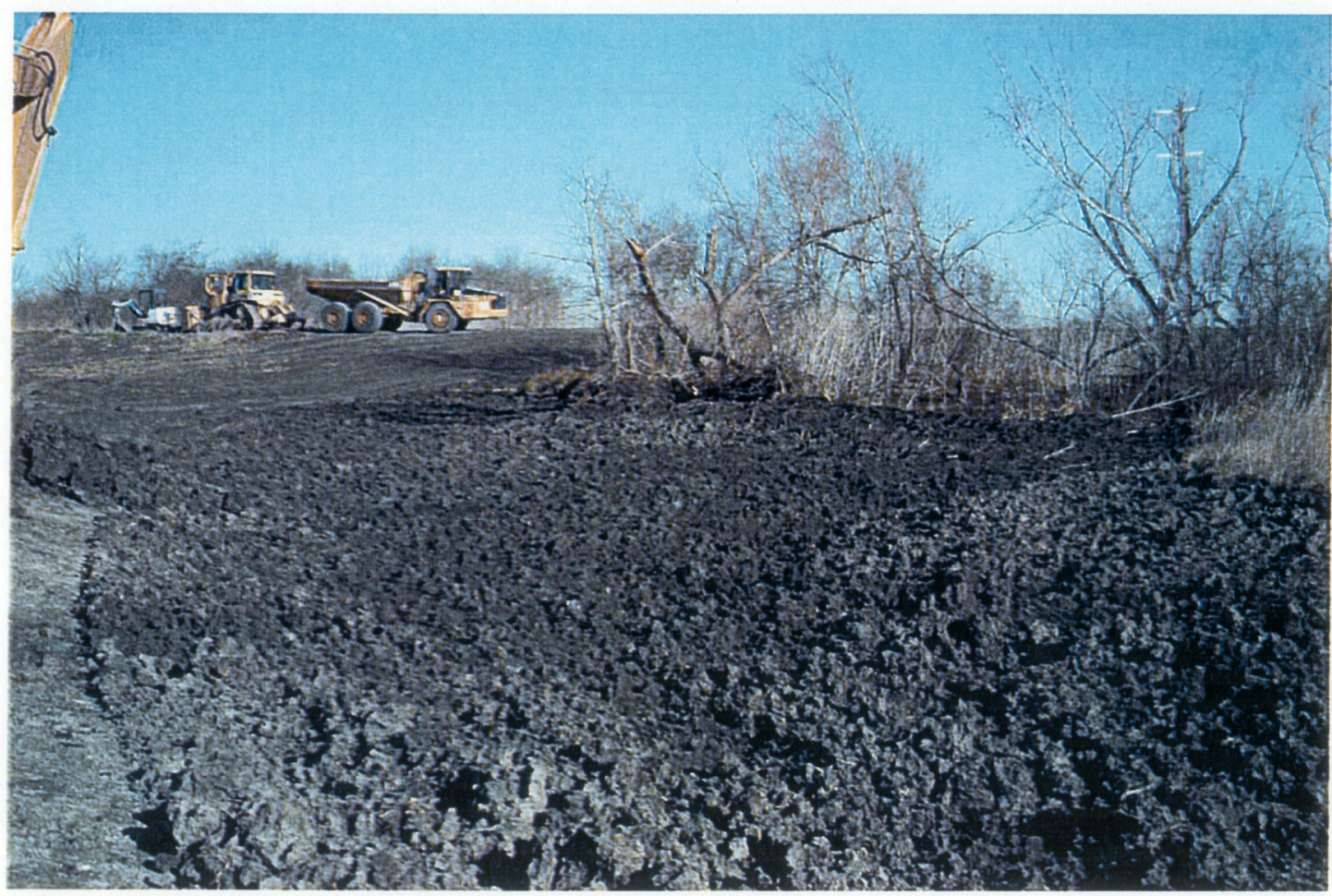

Figure 20. View of BA 2 prior to monitoring (facing north). 


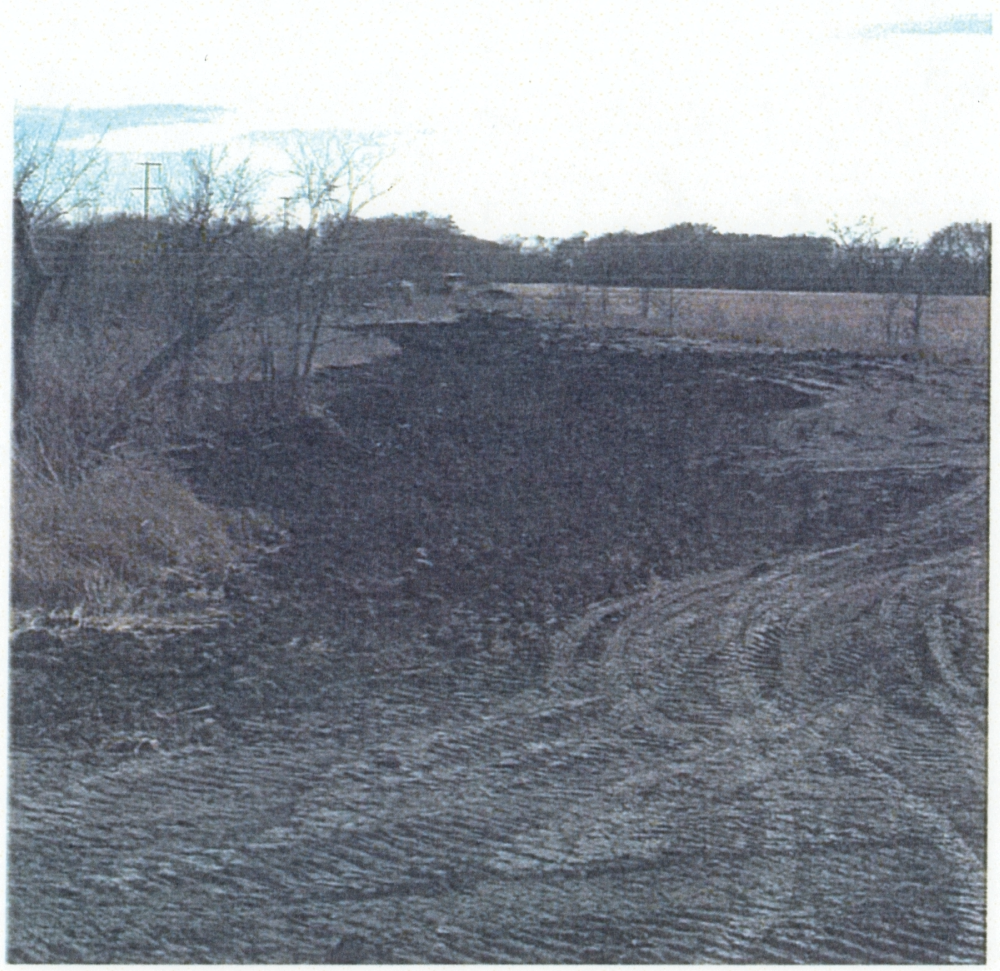

Figure 21. View of BA 2 after monitoring (facing south). 


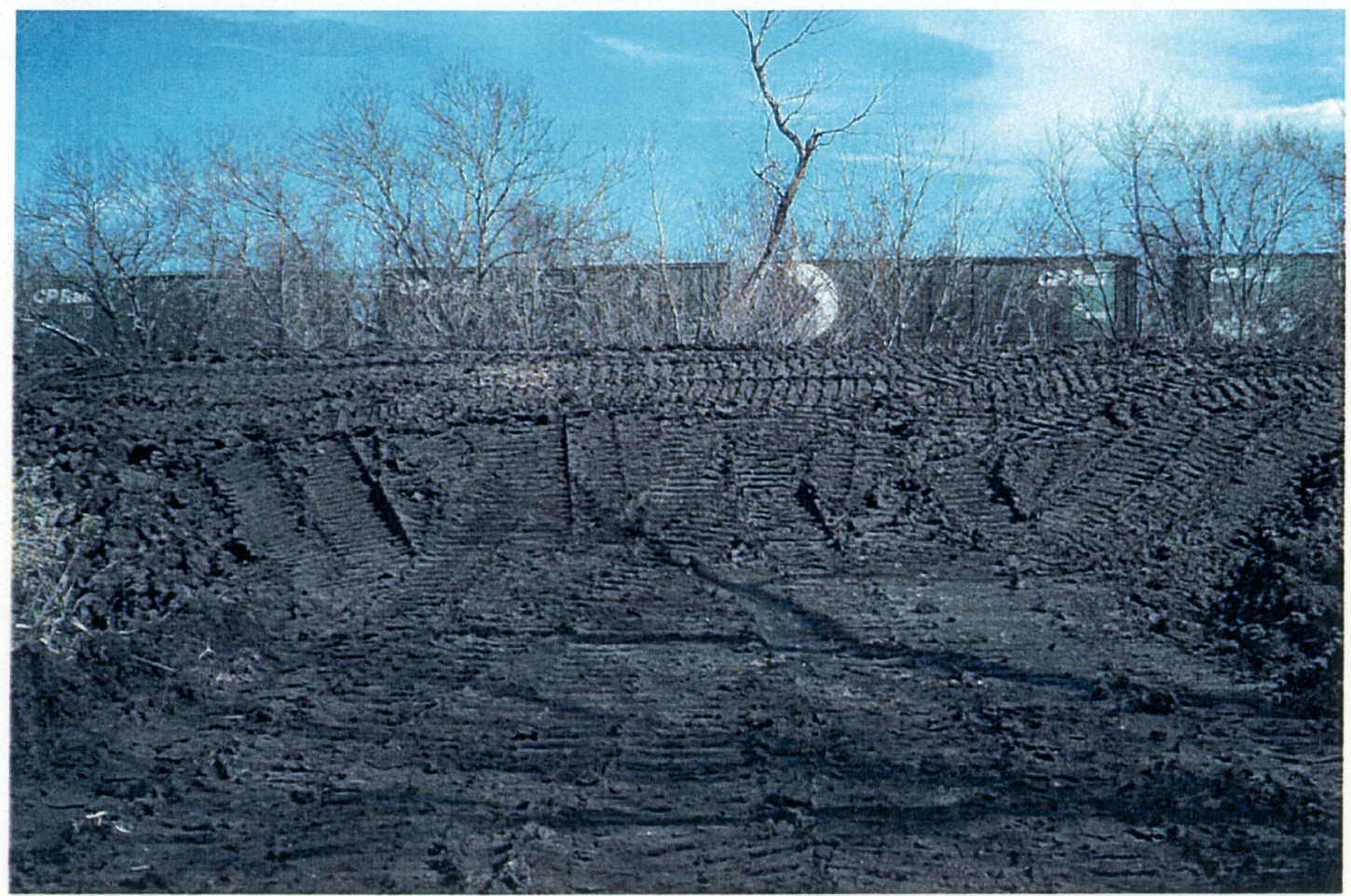

Figure 22. Profile of BA 2 (facing east). 


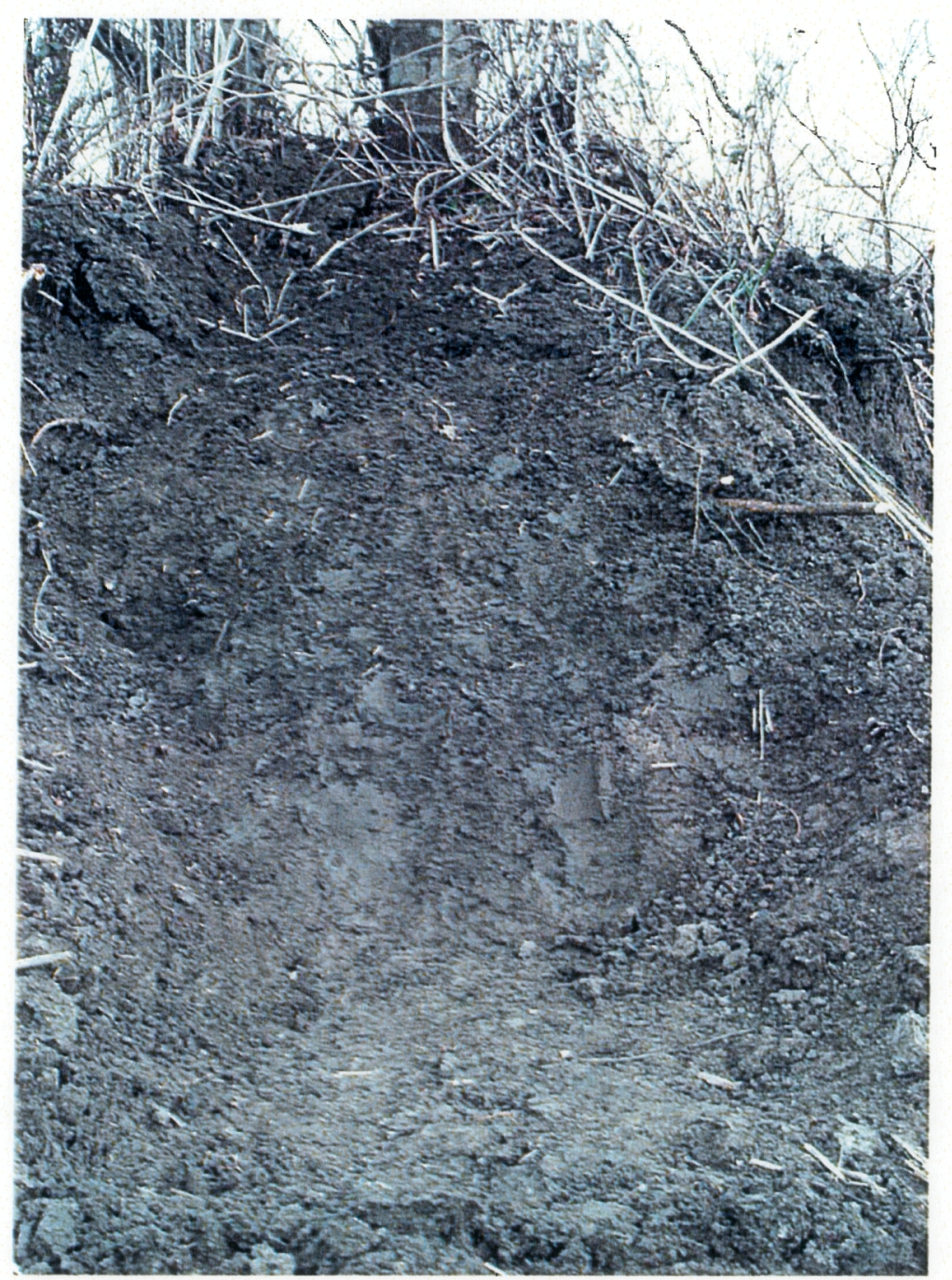

Figure 23. View of LR 3 (facing east). 



\section{REFERENCES CITED}

Beene, D. L.

1996 Cultural Resources Survey of 2.8 Miles of Proposed Pipeline within the L.B.J. National Grassland and Adjoining Areas, Wise County, Texas. Miscellaneous Reports of Investigations No. 127. Geo-Marine, Inc., Plano, Texas.

Bell, R. E., E. B. Jelks, and W. W. Newcomb (assemblers)

1967 A Pilot Study of Wichita Indian Archaeology and Ethnohistory. Submitted to the National Sciences Foundation.

Blair, W. F.

1950 The Biotic Provinces of Texas. Texas Journal of Science 2:93-117.

Brown, D. O. (compiler)

1987 Archeology at Aquilla Lake, 1978-1982 Investigations. 3 Vols. Research Report 81. Texas Archeological Survey, University of Texas, Austin.

Brown, K. L., and S. A. Lebo

1991 Archeological Testing of the Lewisville Lake Shoreline, Denton County, Texas. Institute of Applied Sciences, University of North Texas, Denton.

Bruseth, J. E., and N. A. Kenmotsu

1991 Soldiers of Misfortune: The de Soto Expedition Through Texas. Heritage 9(4):12-17.

Bruseth, J. E., and W. A. Martin (editors)

1987 The Bird Point Island and Adams Ranch Sites: Methodological and Theoretical Contributions to North Central Texas Archaeology. Richland Creek Technical Series, vol. II. Archaeology Research Program, Institute for the Study of Earth and Man, Southern Methodist University, Dallas. 
Bruseth, J. E., McGregor, D. E., and Martin, W. A.

1987 Hunter-Gatherers of the Prairie Margin: Summary of the Prehistoric Archaeological Record. In Hunter-Gatherer Adaptations along the Prairie Margin: Site Excavations and Synthesis of Prehistoric Archaeology, edited by D. E. McGregor and J. E. Bruseth, pp. 229-256. Richland Creek Technical Series, vol. III. Archaeology Research Program, Southern Methodist University, Dallas.

Bruseth, J. E., and R. W. Moir (editors)

1987 Introduction to the Richland Creek Archaeological Project: Environmental Background and Cultural Setting. Richland Creek Technical Series vol. I. Archaeology Research Program, Southern Methodist University, Dallas.

Bureau of Economic Geology

1972 Geologic Atlas of Texas. Dallas Sheet. Revised 1987. Bureau of Economic Geology, University of Texas, Austin.

Campbell, T. N.

1983 Espinosa, Olivares, and the Colorado River Indians, 1709. Sayersville Historical Association Bulletin 3:2-16.

Chandler, B. O., and J. E. Howe

1939 History of Texarkana . . and . . Bowie and Miller Counties, Texas-Arkansas. Texarkana, Texas-Arkansas.

Commercial National Bank of Shreveport, Louisiana (CNB)

1979 The Red River: A Historical Perspective. Moran Publishing, Baton Rouge.

Cooper, J. H., E. Salo, J. M. Enright, D. Shanabrook, E. Burson, and S. M. Hunt

2002 Cultural Resources and Remote Sensing Investigations for Red River Navigation Feasibility Study. (Final Draft) Miscellaneous Report of Investigations No. 235. Geo-Marine, Inc., Plano, Texas.

Crook, W. W., Jr., and R. K. Harris

1952 Trinity Aspect of the Archaic Horizon: The Carrollton and Elam Foci. Bulletin of the Texas Archeological and Paleontological Society 23:7-38.

1954 Traits of the Trinity Aspect Archaic: Carrollton and Elam Foci. The Record 12(1):2-16.

1957 Hearths and Artifacts of Early Man near Lewisville, Texas, and Associated Faunal Material. Bulletin of the Texas Archeological Society 28:7-97.

1958 A Pleistocene Campsite near Lewisville, Texas. American Antiquity 23(3):233246. 
de la Teja, J. F.

1988 Land and Society in $18^{\text {th }}$ Century San Antonio de Bexar, a Community on New Spain's Northern Frontier. Unpublished Ph.D. dissertation, University of Texas, Austin.

Dawson, G. L., and T. L. Sullivan

1973 Excavations at Lake Lavon, 1969. Research Report No. 25. Archaeology Research Program, Southern Methodist University, Dallas.

Diamond, D. D., D. H. Riskind, and S. L. Orzell

1987 A Framework for Plant Communities Classification and Conservation in Texas. Texas Journal of Science 39(3):203-221.

Duffield, L. F.

1963 The Strawn Creek Site: A Mixed Archaic and Neo-American Site at Navarro Mills Reservoir, Navarro County, Texas. Report submitted to the National Park Service by the Texas Archeological Salvage Project, University of Texas, Austin..

Elam, R.

2002 Johnson County. The Handbook of Texas Online. Accessed 26 November 2002.

Ensor, H. B., J. W. Saunders, and C. S. Mueller-Wille

1992 Prehistoric Synthesis. In An Archeological Survey of the Proposed South Bend Reservoir Area: Young, Stephens, and Throckmorton Counties, Texas, edited by J. W. Saunders, C. S. Mueller-Wille, and D. L. Carlson, pp. 259-303. Archeological Surveys No. 6. Archeological Research Laboratory, Texas A\&M University, College Station.

Fehrenbach, T. R.

1985 LoneStar: A History of Texas and the Texans. Collier Books, New York.

Ferring, C. R.

1975 An Archaeological Survey of the Grapevine Dam Area, Tarrant County, Texas. Archaeology Research Program, Southern Methodist University, Dallas.

1987 Geoarchaeology of Site 41CO141: A Late Holocene Locality in the Upper Trinity Basin. In Test Excavations at 41CO141, Ray Roberts Reservoir, Cooke County, Texas, edited by D. J. Prikryl and B. C. Yates, pp. 1-54. Contributions in Archaeology No. 4. Institute of Applied Sciences, North Texas State University, Denton.

1989 The Aubrey Clovis Site: A Paleoindian Locality in the Upper Trinity River Basin. Current Research in the Pleistocene 6:9-11. 
Ferring, C. R. (with contributions by S. A. Elias, S. A. Hall, H. Haas, J. D. Humphrey, E. L. Lundelius, Jr., R. Neck, and B. C. Yates)

2001 The Archaeology and Paleoecology of the Aubrey Clovis Site (41DN479), Denton County, Texas. Center for Environmental Archaeology, Department of Geography, University of North Texas, Denton.

Ferring, C. R., and B. C. Yates

1997 Holocene Geoarchaeology and Prehistory of the Ray Roberts Lake Area. Institute of Applied Sciences, University of North Texas, Denton.

1998 Archaeological Investigations at Five Prehistoric Sites at Lewisville Lake, Denton County, Texas. Center for Environmental Archaeology, University of North Texas, Denton.

Fields, R. C.

1995 The Archeology of the Post Oak Savannah of East Central Texas. Bulletin of the Texas Archeological Society 66:301-330.

Flores, D. L.

1984 Jefferson \& Southwestern Exploration: The Freeman \& Custis Accounts of the Red River Expedition of 1806. University of Oklahoma Press, Norman.

Gill-King, H.

1987 The Human Osteology of 41CO141. In Text Excavations at 41CO141, Ray Roberts Reservoir, Cooke County, Texas, edited by D. J. Prikryl and B. C. Yates, pp. 101-104. Contributions in Archaeology No. 4. Institute of Applied Sciences, North Texas State University, Denton.

Gilmore, K.

1991 French, Spanish, and Indian Interaction in Colonial Texas. Paper presented at the Symposium on Historic Indian Period Archeology and Ethnohistory. Council of Texas Archeologists, Spring Meeting, April 5, 1991.

Goldfield, D. R.

1982 Cotton Fields and Skyscrapers: Southern City and Region. Johns Hopkins University Press, Baltimore.

Guy, J. A.

1990 Previous Archeological Investigations. In The Archeology and Bioarcheology of the Gulf Coastal Plain, by D. A. Story, J. A. Guy, B. A. Burnett, M. D. Freeman, J. C. Rose, D. G. Steele, B. W. Olive, and K. J. Reinhard, pp. 27-130. 2 Vols. Research Series No. 38. Arkansas Archeological Survey, Fayetteville.

Harris, R. K., and I. M. Harris

1970 A Bison Kill on Dixon's Branch, Site 27A2-5, Dallas County, Texas. The Record 27(1):1-4. 
Harris, R. K., and D. A. Suhm (editors)

1963 An Appraisal of the Archeological Resources of Forney Reservoir, Collin, Dallas, Kaufman, and Rockwall Counties, Texas. Texas Archeological Salvage Project, University of Texas, Austin.

Hester, T. R.

1989 Texas and Northeastern Mexico: An Overview. In Archaeological and Historical Perspectives on the Spanish Borderlands West, edited by D. H. Thomas, pp. 191211. Columbian Consequences, vol. 1. Smithsonian Institution Press, Washington, D.C.

Hillard, S. B.

1990 Plantations and the moulding of the Southern landscape. In Making of the American Landscape, edited by N. P. Crozen, pp. 104-126. Routledge Press, New York.

Hofman, J. L.

1989a Prehistoric Culture History-Hunters and Gatherers in the Southern Great Plains. In From Clovis to Comanchero: Archeological Overview of the Southern Great Plains, by J. L. Hofman, R. L. Brooks, J. S. Hays, D. W. Owsley, R. L. Jantz, M. K. Marks, and M. H. Manhein, pp. 25-60. Research Series No. 35. Arkansas Archeological Survey, Fayetteville.

1989b Protohistoric Culture History on the Southern Great Plains. In From Clovis to Comanchero: Archeological Overview of the Southern Great Plains, by J. L. Hofman, R. L. Brooks, J. S. Hays, D. W. Owsley, R. L. Jantz, M. K. Marks, and M. H. Manhein, pp. 91-100. Research Series No. 35. Arkansas Archeological Survey, Fayetteville.

Hofman, J. L., R. L. Brooks, J. S. Hays, D. W. Owsley, R. L. Jantz, M. K. Marks, and M. H. Manhein

1989 From Clovis to Comanchero: Archeological Overview of the Southern Great Plains. Research Series No. 35. Arkansas Archeological Survey, Fayetteville.

Jensen, H. P., Jr.

1968 Report on Excavations at the Field Ranch Site (X41CO10), Cooke County, Texas. Bulletin of the Texas Archeological Society 39:133-146.

John, E. A. H.

1975 Storms Brewed in Other Men's Worlds: The Confrontation of Indians, Spanish, and French in the Southwest, 1540-1795. University of Nebraska Press, Lincoln.

Johnson, L., Jr.

1989 Great Plains Interlopers in the Eastern Woodlands During Late Paleo-Indian Times: The Evidence from Oklahoma, Texas, and Areas Close By. Report No. 36. Office of the State Archeologist, Texas Historical Commission, Austin. 
Jurney, D. H., and R. W. Moir (editors)

1987 Historic Buildings, Material Culture, and People of the Prairie Margin. Richland Creek Technical Series, vol. V. Archaeology Research Program, Southern Methodist University, Dallas.

Kelley, D. B., and C. L. Coxe

1996 Cultural Resources Survey of Levee Rehabilitation/Restoration Areas Along the Red River Between Fulton, Arkansas, and the Louisiana State Line: Items 4, 5, and 9. Coastal Environments, Inc., Baton Rouge. Submitted to the U.S. Army Corps of Engineers, Vicksburg District.

Lorrain, D., and N. Hoffrichter

1968 The Lower Rockwall Site, Rockwall County, Texas. Archaeological Salvage Project, Southern Methodist University, Dallas.

Lynott, M. J.

1975 Archaeological Excavations at Lake Lavon, 1974. Contributions in Anthropology No. 16. Department of Anthropology, Southern Methodist University, Dallas.

1977 A Regional Model of Archaeological Research in North Central Texas. Unpublished Ph.D. dissertation, Southern Methodist University, Dallas.

1981 A Model of Prehistoric Adaptation in Northern Texas. Plains Anthropologist 26(92):97-110.

May, R. E.

1991 Young American Males and Filibustering in the Age of Manifest Destiny: The United States Army as Cultural Mirror. The Journal of American History 78 (3):857-886.

McCroskey, V. K.

1997 Delta County. The Handbook of Texas Online. Accessed 26 November 2002.

McDonald, W. L.

1978 Dallas Rediscovered: A Photographic Chronicle of Urban Expansion 1870-1925. Dallas Historical Society.

McGowen, J. H., C. V. Proctor, W. T. Haenggi, D. F. Reaser, and V. E. Barnes

1972 Geologic Atlas of Texas. Dallas Sheet. Bureau of Economic Geology. University of Texas, Austin.

Meade, W. D., G. Chervenka, and J. M. Greenwade

1974 Soil Survey of Navarro County, Texas. U.S. Department of Agriculture, Soil Conservation Service, Washington, D.C.

Meltzer, D. J.

1987 The Clovis Paleoindian Occupation of Texas: Results of the Texas Clovis Fluted Point Survey. Bulletin of the Texas Archeological Society 57:27-68. 
Meltzer, D. J., and M. R. Bever

1995 Paleoindians of Texas: An Update on the Texas Clovis Fluted Point Survey. Bulletin of the Texas Archeological Society 66:47-81.

Moir, R. W., and D. H. Jurney (editors)

1987 Pioneer Settlers, Tenant Farmers, and Communities: Objectives, Historical Background, and Excavations. Richland Creek Technical Series, vol. IV. Archaeology Research Program, Southern Methodist University, Dallas.

Morgan, L. W.

1975 An Empirical Analysis of a Pre-Neo-American Site in Dallas County, Texas. Unpublished Master's thesis, University of Texas, Arlington.

Morris, V., and B. Morris

1970 Excavation of Bison Remains in Northwest Dallas County. The Record 27(1):2-5.

Newcomb, W. W., Jr.

1961 The Indians of Texas: From Prehistoric to Modern Times. University of Texas Press, Austin.

1993 Historic Indians of Central Texas. Bulletin of the Texas Archeological Society 64:1-63.

Newcomb, W. W., and T. N. Campbell

1982 Southern Plains Ethnohistory: A Reexamination of the Escanjaques, Ahijados, and Cuitoas. In Pathways to Plains Prehistory: Anthropological Perspectives of Plains Natives and Their Pasts, edited by D. G. Wyckoff and J. L. Hofman, pp. 29-43. Oklahoma Anthropological Society Memoir 3, and The Cross Timbers Heritage Association Contributions 1, Duncan, Oklahoma.

Peter, D. E., and M. B. Cliff (editors)

1990 Intensive Archeological Survey and Archival Investigations at the Red River Army Depot and Lone Star Army Ammunition Plant, Bowie County, Texas. RRAD/LSAAP Archeological Technical Series, Reports of Investigations No. 2. Geo-Marine, Inc., Plano, Texas.

Peter, D. E., and D. E. McGregor (editors)

1988 Late Holocene Prehistory of the Mountain Creek Drainage. Joe Pool Lake Archaeology Project, vol. I. Archaeology Research Program, Southern Methodist University, Dallas.

Pool, W. C.

1975 A Historical Atlas of Texas. Encino Press, Austin.

Prikryl, D.

1990 Lower Elm Fork Prehistory: A Redefinition of Cultural Concepts and Chronologies along the Trinity River, North-Central Texas. Report 37. Office of the State Archeologist, Texas Historical Commission, Austin. 
1993 Regional Preservation Plan for Archeological Resources, Prairie-Savanna Archeological Region: Introduction. In Archeology in the Eastern Planning Region, Texas: A Planning Document, edited by N. A. Kenmotsu and T. K. Perttula, pp. 191-204. Cultural Resource Management Report 3. Department of Antiquities Protection, Texas Historical Commission, Austin.

Prikryl, D. J., and B. C. Yates

1987 Test Excavations at 41CO141, Ray Roberts Reservoir, Cooke County, Texas. Contributions in Archaeology No. 4. Institute of Applied Sciences, North Texas State University, Denton.

Ross, R. E.

1966 The Upper Rockwall and Glen Hill Sites, Forney Reservoir, Texas. Papers of the Texas Archeological Salvage Project No. 9. University of Texas, Austin.

Sherman, E. P.

2001 Early Twentieth Century Logging Industry Historic Resources on the National Forest and Grasslands in Texas. National Register of Historic Places Multiple Property Documentation Form.

Skinner, S. A., M. B. Cliff, L. Baird, A. B. Amerson, Jr., J. Benett, A. R. Faust, J. Kaskey, K. Ludden, M. D. Northern, A. Pitchford, J. Raley, D. G. Shaddox, and D. Shanabrook

1982 Cultural Resources Survey. The Archaeology and History of Lake Ray Roberts, vol. 1. Cultural Resources Report 82-6. Environmental Consultants, Inc., Dallas.

Smith, F. T.

1991 The Kadohadacho Indians and the Louisiana-Texas Frontier, 1803-1815. Southwestern Historical Quarterly 95(2):177-204.

1996 The Caddos, the Wichitas, and the United States, 1846-1901. Texas A\&M University Press, College Station.

Sollberger, J. B.

1953 The Humphrey Site. The Record 11(3):11-14.

Sorrow, W., H. J. Shafer, and R. Ross

1966 The Pecan Springs Site, Bardwell Reservoir, Texas. Papers of the Texas Archeological Salvage Project No. 10. University of Texas, Austin.

Stanford, D.

1981 Who's On First? Science 81 2(5):91-92.

Stephenson, R. L.

1949 Archaeological Survey of Lavon and Garza-Little Elm Reservoirs: A Preliminary Report. Bulletin of the Texas Archeological and Paleontological Society 20:21-62.

1950 Archeological Survey of Garza-Little Elm Reservoir, Denton County, Texas. River Basin Surveys, Austin Office, Smithsonian Institution, Washington, D.C. 
1970 Archeological Investigations in the Whitney Reservoir Area, Central Texas. Bulletin of the Texas Archeological Society 41:37-277.

Story, D. A.

1965 The Archeology of Cedar Creek Reservoir, Henderson and Kaufman Counties, Texas. Bulletin of the Texas Archeological Society 36:163-257.

1985 Adaptive Strategies of Archaic Cultures of the West Gulf Coastal Plain. In Prehistoric Food Production in North America, edited by R. I. Ford, pp. 19-56. Anthropological Papers No. 75. Museum of Anthropology, University of Michigan, Ann Arbor.

1990 Cultural History of the Native Americans. In The Archeology and Bioarcheology of the Gulf Coastal Plain, by D. A. Story, J. A. Guy, B. A. Burnett, M. D. Freeman, J. C. Rose, D. G. Steele, B. W. Olive, and K. J. Reinhard, pp. 163-366. Research Series No. 38. Arkansas Archeological Survey, Fayetteville.

Tindall G. B., and D. E. Shi

1996 America: A Narrative History, Vol. I. Fourth ed. W. W. Norton \& Company, New York.

U.S. Geological Survey

1961 7.5-Minute Topographic Map Series, Chatfield, Texas, quadrangle.

Webb, W. P. (editor-in-chief)

1952a The Handbook of Texas, vol. 1. Texas State Historical Association, Austin.

1952b The Handbook of Texas, vol. 2. Texas State Historical Association, Austin.

Webb, W. P., and H. B. Carroll (editors)

1952 The Handbook of Texas. 2 vols. Texas State Historical Association, Austin.

Wedel, M. M.

1978 La Harpe's 1719 Post on Red River and Nearby Caddo Settlements. Bulletin 30. The Texas Memorial Museum, University of Texas, Austin.

Winship, G. P. (translator and editor)

1990 The Journey of Coronado: 1540-1542. Reprint of 1904 translation. Fulcrum Publishing, Golden, Colorado.

Woodall, J. N.

1967 The Upper Tucker Site. In A Pilot Study of Wichita Indian Archeology and Ethnohistory, edited by R. E. Bell, E. B. Jelks, and W. W. Newcomb, pp. 3-14. Final Report for National Science Foundation Grant GS-964.

Works Progress Administration (WPA)

1940 Texas: A Guide to the Lone Star State. American Guide Series. Hastings House, New York. 
Yates, B. C. and Ferring, C. R.,

1986 An Assessment of the Cultural Resources in the Trinity River Basin, Dallas, Tarrant, and Denton Counties. Institute of Applied Sciences, University of North Texas, Denton.

Yedlowski, J. L., K. J. Shaunessy, D. H. Jurney, and J. M. Adovasio

1998 Archaeological Investigations in Support of the Superconducting Super Collider, Ellis County, Texas. Archaeology Research Program, Mercyhurst College, Erie, New York.

Young, B., and M. B. Collins

1989 A Cache of Blades with Clovis Affinities from Northeastern Texas. Current Research in the Pleistocene 6:26-28.

Zinn, $\mathrm{H}$.

1995 A People's History of the United States 1492-Present. Revised edition. HarperPerennial, New York. 